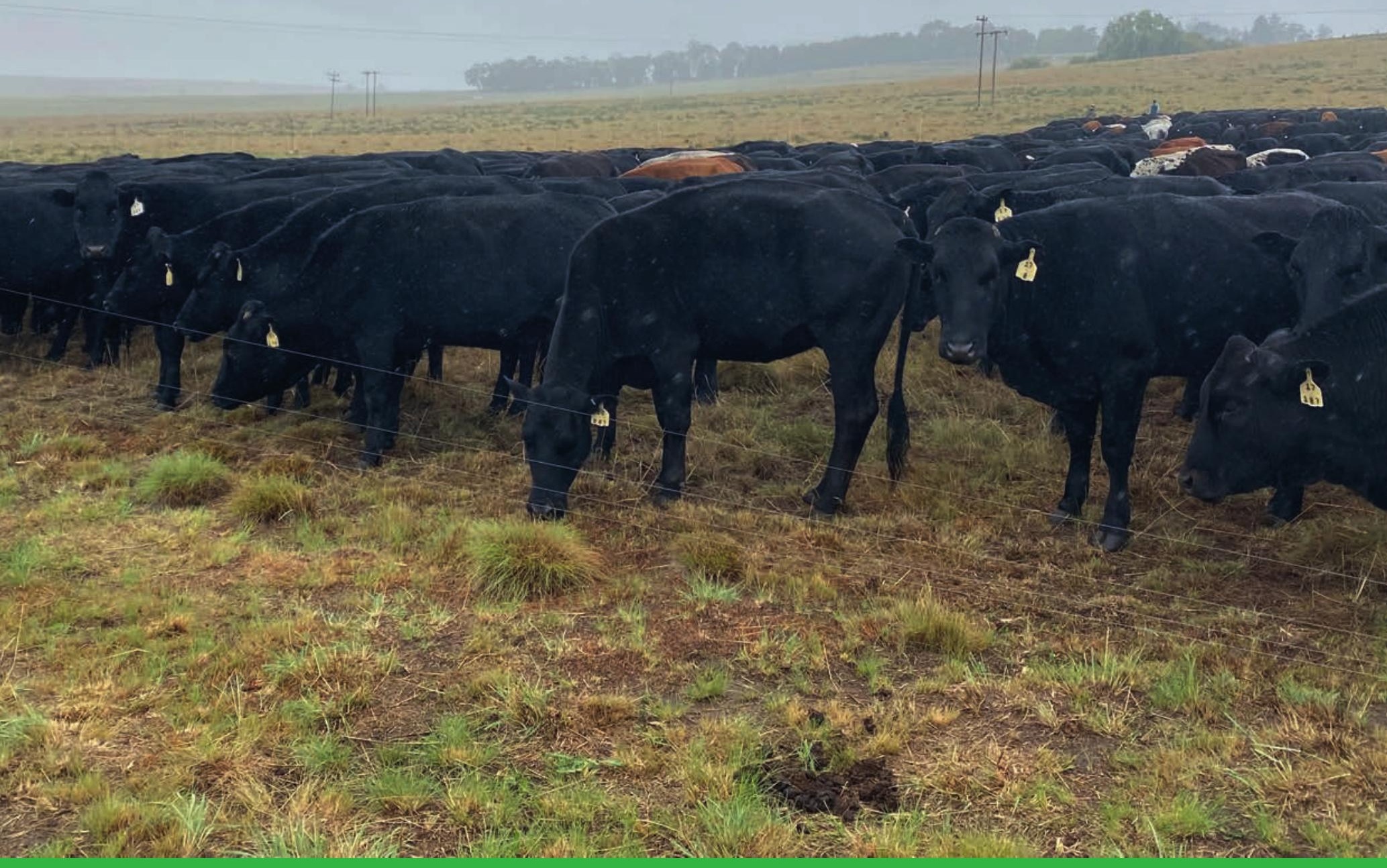

\title{
Potential role of Conservation Agriculture in South Africa for carbon sequestration for climate mitigation
}

A provisional research agenda

Saskia Keesstra, Angelinus Franke, Henk Wösten, Nester Mashingaidze 



\section{Potential role of Conservation Agriculture in South Africa for carbon sequestration for climate mitigation}

A provisional research agenda

Saskia Keesstra ${ }^{1}$, Angelinus Franke $^{2}$, Henk Wösten $^{1}$, Nester Mashingaidze $^{2}$

1 Wageningen Environmental Research, The Netherlands

2 University of the Free State, South Africa

This study was carried out by Wageningen Environmental Research and subsidised by the Ministry of Agriculture, Nature and Food Quality (project number BO-43-003.01-020-WENR).

Wageningen Environmental Research

Wageningen, July 2020

Approved for publication:

Mirjam Hack-ten Broeke, team manager Soil, Water and Land use (SWL)

Report 3024

ISSN 1566-7197

ISBN 978-94-6395-458-7 
Keesstra, S.D., Franke, A., Wösten, H., Mashingaidze, N., 2020. Potential role of Conservation Agriculture in South Africa for carbon sequestration for climate mitigation; A provisional research agenda. Wageningen, Wageningen Environmental Research, Report 3024. 52 pp.; 8 fig.; 4 tab.; 49 ref.

Tijdens een workshop en veldbezoek in december 2019 in Zuid-Afrika bespraken we de rol van bodem $C$ van natuurbehoud en koolstofvastlegging voor klimaatbeperking. De inzichten van de workshop omvatten: (i) Vee integreren in gewassystemen om circulariteit te bereiken, (ii) Economische en ecologische duurzaamheid is mogelijk zonder subsidie, (iii) De transitie naar duurzame landbouw kan ook traag zijn: Elke stap in de richting van duurzaamheid als een goede, (iv) Visie en liefde voor het land: een goede boer is een rentmeester van het land; en (v) Manieren om praktische, maar holistische oplossingen te vinden voor elke boerderij.

During a workshop and field visit in December 2019 in South Africa we discussed the Role soil C of Conservation Agriculture and carbon sequestration for climate mitigation. The insights of the workshop comprised of: (i) Integrating livestock into crop systems to achieve circularity, (ii) Economic and environmental sustainability is possible without subsidy, (iii) The transition towards sustainable farming can also be slow: Every step into the direction of sustainability if a good one, (iv) Vision and love for the land: a good farmer is a steward of the land; and (v) Ways to find hands-on local, but holistic solutions for every farm.

Keywords: Climate mitigation, Carbon sequestration, South Africa, Conservation Agriculture, regenerative agriculture

The pdf file is free of charge and can be downloaded at https://doi.org/10.18174/526557 or via the website www.wur.nl/environmental-research (scroll down to Publications - Wageningen Environmental Research reports). Wageningen Environmental Research does not deliver printed versions of the Wageningen Environmental Research reports.

2020 Wageningen Environmental Research (an institute under the auspices of the Stichting Wageningen Research), P.O. Box 47,6700 AA Wageningen, The Netherlands, $\mathrm{T}+31$ (0)317 4807 00, www.wur.nl/environmental-research. Wageningen Environmental Research is part of Wageningen University \& Research.

- Acquisition, duplication and transmission of this publication is permitted with clear acknowledgement of the source.

- Acquisition, duplication and transmission is not permitted for commercial purposes and/or monetary gain.

- Acquisition, duplication and transmission is not permitted of any parts of this publication for which the copyrights clearly rest with other parties and/or are reserved.

Wageningen Environmental Research assumes no liability for any losses resulting from the use of the research results or recommendations in this report.

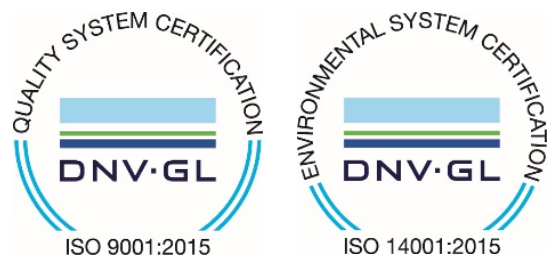

In 2003 Wageningen Environmental Research implemented the ISO 9001 certified quality management system.

Since 2006 Wageningen Environmental Research has been working with the ISO 14001 certified environmental care system.

By implementing the ISO 26000 guideline, Wageningen Environmental Research can manage and deliver its social responsibility.

Wageningen Environmental Research report 3024 | ISSN 1566-7197

Photo cover: Ultra-high density grazing in Reitz, South Africa (photo by Saskia Keesstra) 


\section{Contents}

Verification $\quad 5$

Summary 7

1

$\begin{array}{lr}\text { Introduction } & 9\end{array}$

1.1 South African context 9

1.2 Problem definition and project objective 9

1.3 Project execution 9

$\begin{array}{lll}1.4 & \text { Workshop and expected outcomes } & 10\end{array}$

$2 \quad$ International setting of the project $\quad 11$

2.1 The Sustainable Development Goals 11

$\begin{array}{lll}2.2 & 4 / 1000 \text { initiative } & 12\end{array}$

2.3 European Joint Programme on SOIL 13

$\begin{array}{lll}2.4 & \text { CIRCASA } & 13\end{array}$

3 Definitions $\quad 15$

$\begin{array}{ll}\text { 3.1 What is Conservation Agriculture? } & 15\end{array}$

$\begin{array}{ll}3.2 \text { What is circular agriculture? } & 16\end{array}$

$4 \quad$ Importance of soil organic matter 18

$\begin{array}{lll}4.1 & \text { Relevance } & 18\end{array}$

$\begin{array}{lll}4.2 & \text { Interactions } & 19\end{array}$

$5 \quad$ Effect of soil organic matter on crop yield 22

$\begin{array}{lll}6 & \text { Effect of soil organic matter on climate mitigation } & 23\end{array}$

$\begin{array}{lll}7 & \text { Ways to increase organic matter content } & 25\end{array}$

$8 \quad$ The South African Context $\quad 27$

$\begin{array}{lll}8.1 & \text { Soil organic carbon status of soils in Southern Africa } & 27\end{array}$

8.2 Conservation agriculture in Southern Africa 28

8.3 Studies on CA impacting SOC in Southern Africa 29

8.4 Enabling conditions for sustainable agricultural management in South Africa 32

$9 \quad$ Outcomes Workshop 33

10 Roadmap for research in South Africa regarding sustainable soil management for Climate Change Mitigation $\quad 35$

$\begin{array}{ll}\text { References } & 37\end{array}$

$\begin{array}{lll}\text { Annex } 1 & \text { Program workshop } & \mathbf{4 0}\end{array}$

$\begin{array}{lll}\text { Annex } 2 & \text { List of participants of the workshop } & 41\end{array}$

Annex 3 Workshop 1 set up: Perception 42

Annex 4 Workshop 2 set up: Aspirational targets 44

Annex 5 Workshop 3 set up: barriers and solutions 46

$\begin{array}{lll}\text { Annex } 6 & \text { Two-pager deliverable published in Agro-berichten } & 48\end{array}$

$\begin{array}{lll}\text { Annex } 7 & \text { Landbouwberichten } & 51\end{array}$ 



\section{Verification}

Report: 3024

Project number: 5200045597

Wageningen Environmental Research (WENR) values the quality of our end products greatly. A review of the reports on scientific quality by a reviewer is a standard part of our quality policy.

Approved team leader responsible for the contents,

name: Mirjam Hack-ten Broeke

date: July 62020 


\section{Summary}

South Africa has a dynamic and active group of farmers, agricultural researchers and extension workers testing and promoting the use of CA principles with farmers being at the centre of the innovation. In the Netherlands, circular agriculture has become a key focus of agricultural development. As agricultural research in both South Africa and the Netherlands is highly developed, there are ample possibilities for joined research projects. Based on a constructive workshop and field visit from December 3-5, 2019 on "The role of soil C in Conservation Agriculture and carbon sequestration in South Africa" the following outline for research on CA has been developed. After a lively workshop in Bloemfontein organised by the university of the Free State (Linus Franke and Nester Mashingaidze) and Wageningen Environmental Research (Saskia Keesstra and Henk Wösten).

In the workshop we discussed the benefits of Conservation Agriculture (CA) as a farming system that promotes minimum soil disturbance (i.e. no tillage), maintenance of a permanent soil cover, and diversification of plant species. It enhances biodiversity and natural biological processes above and below the ground surface, which contributes to increased water and nutrient use efficiency and to improved and sustained crop production.

In our workshop there was a strong voice to take conservation agriculture to the next level of regenerative agriculture, as the ultimate goal. However, this goal has to be reached in manageable steps.

Lessons learned from the workshop and field visit were:

1. Integrating livestock into crop systems to achieve circularity.

2. Economic and environmental sustainability is possible without subsidy.

3. The transition towards sustainable farming can also be slow: Every step into the direction of sustainability if a good one.

4. Vision and love for the land: a good farmer is a steward of the land.

5. Ways to find hands-on local, but holistic solutions for every farm. 


\section{Introduction}

In both the Netherlands and South Africa research on soil, water and land use is at the forfront of science. Especially integrated crop and livestock management in relation to the climatic conditions has been focus of study. In these studies innovative practices such as precision agriculture and conservation agriculture are seen as an option for sustainable land management and working towards a circular food system. In the light of climate mitigation, these agricultural practices are also interesting to consider. Storing carbon in soils is seen as one option to mitigate climate change. The 4 per 1000 initiative is one example of the ambition and potential of soils for carbon sequestration. Conservation agriculture is seen as a way to promote this. However, many questions remain that need to be answered to know the real potential of management options like conservation agriculture such as what type of $C$ is needed to sustain crop growth, through which routes and mechanisms (e.g. nutrient and water availability) do different soil $C$ fractions stimulate crop growth?

\section{$1.1 \quad$ South African context}

In South Africa Conservation Agriculture has been fairly widely accepted by dryland crop farmers in the winter rainfall areas of the Western Cape. In the summer cropping areas of central and eastern South Africa, this practice has been less widely adopted. With the climate target in mind, agricultural soils are seen as a potential to store carbon in soils for climate mitigation. However, it is unknown how much carbon can be stored in the different types of soil, and which conditions (climatic, soil, agricultural management) are needed for that.

In international literature (e.g. CIRCASA project) general information is available, however, this need to be aligned and made useful for the South African setting.

\subsection{Problem definition and project objective}

For large-scale implementation of Conservation Agriculture for circular sustainable agriculture and climate change mitigation through soil carbon sequestration, an overview is lacking of current scientific insights and potential barriers to adopt CA in different parts of South Africa.

The objective of this project is to develop, through a literature review and a workshop, a research agenda that will be guiding towards circular sustainable agriculture working on climate change mitigation through soil carbon sequestration. The collaboration with European partners (WUR) and projects on this topic knowledge can be shared and implemented in the South African context. South African running projects in different climatic and soil regions can form an excellent case study to test general hypothesis on the soil carbon sequestration potential of Conservation Agriculture.

\subsection{Project execution}

The first part of the project focused on collecting literature in and outside South Africa on soil carbon sequestration. Specific attention was given to the role of conservation agriculture. The main focus was on the changes in soil physical parameters and changes in surface conditions of fields managed with conservation agricultural practices. Attention was given to differences in climatic and soil conditions.

For the international setting findings of the CIRCASA project were incorporated. The CIRCASA (Coordination of International Research Cooperation on soil Carbon Sequestration in Agriculture; https://www.circasa-project.eu/) aims to develop international synergies concerning research and knowledge exchange in the field of carbon sequestration in agricultural soils at European Union and global levels, with active engagement of all relevant stakeholders. 
After the literature assessment a workshop was held in South Africa in December 2019 where key stakeholders were invited to participate and give their opinion on our findings and how this relates to the agricultural, climatic, soil settings they are working in. Key stakeholders in South Africa are universities, the Agricultural Research Council, and Grain SA. The University of the Free State was co-organizer of the workshop and co-author of the literature review and final report.

The target group was composed of South African researchers at universities and research institutes working on the implementation of conservation agriculture with the aim to contribute to circular sustainable agriculture and climate mitigation.

\subsection{Workshop and expected outcomes}

The workshop was organized by the University of the Free State in collaboration with Wageningen University and Research was held on the 3rd and 4th of December 2019. Informative lectures by scientists for the invited stakeholders were given and three workshops were held to exchange information from scientists to the key stakeholders in South Africa working with Conservation Agriculture.

The first draft report formed the basis of the workshop, and this report is the updated final version where the additional information that was collected at the workshop is incorporated. 


\section{International setting of the project}

This project links to International policies such as the Sustainable Development Goals, the UN Climate conventions, Common Agricultural Policies, 4 per 1000 initiative, EU Soil Thematic Strategies, that all aim to work towards the common societal goals: Climate Change Mitigation and Adaptation, Food security and sustainable use of ecosystem services.

\subsection{The Sustainable Development Goals}

In Keesstra et al., (2016) an inventory of the link between soil science, soil functions, ecosystem services and finally the SDGs was described. From this analysis it is clear that there are several SDGs where soils play a more important role than in others. Especially SDG15: Life on Land, SDG13: Climate Action and SDG2: Zero Hunger rely heavily on soils as a natural resource.

Good agricultural management makes use of ecosystem services and can even contribute to them.

Even though soil-related Climate Change Mitigation and Adaptation strategies both aim for storing carbon in the soil, their approaches are fundamentally different, therefore we have separated these two topics. Soil carbon storage helps SDG13 (Climate Action) in two ways: (i) by creating sinks for atmospheric carbon dioxide, and (ii) improving resilience to climate change, such as droughts (Lal, 2016; Keesstra et al., 2016). The first one mainly focusses on climate change mitigation, the second on climate change adaptation. Furthermore, other interactions between soils and climate change have been described in recent literature: increased wind and water erosion due to more erratic and high intensity rainfall and wind speeds (Borelli et al 2014; Cerda et al., 2018), increased land slide risk due to heavy rainfall events (Garriano and Guzzetti, 2016), increased salinization due to prolonged droughts (Kreuzwieser and Gessler, 2010), increased soil organic matter loss due to increased temperature (Smith et al., 2007, EEA, 2012) and thawing permafrost (Crowther et al., 2016). In Figure 1 the SDGs are grouped in three layers: economy, society and biosphere, that are connected by SDG 17 (the arrow).

The key message is that one goal cannot be achieved without the other, therefore we need to find solutions that consider the benefits and trade-offs for all goals. 


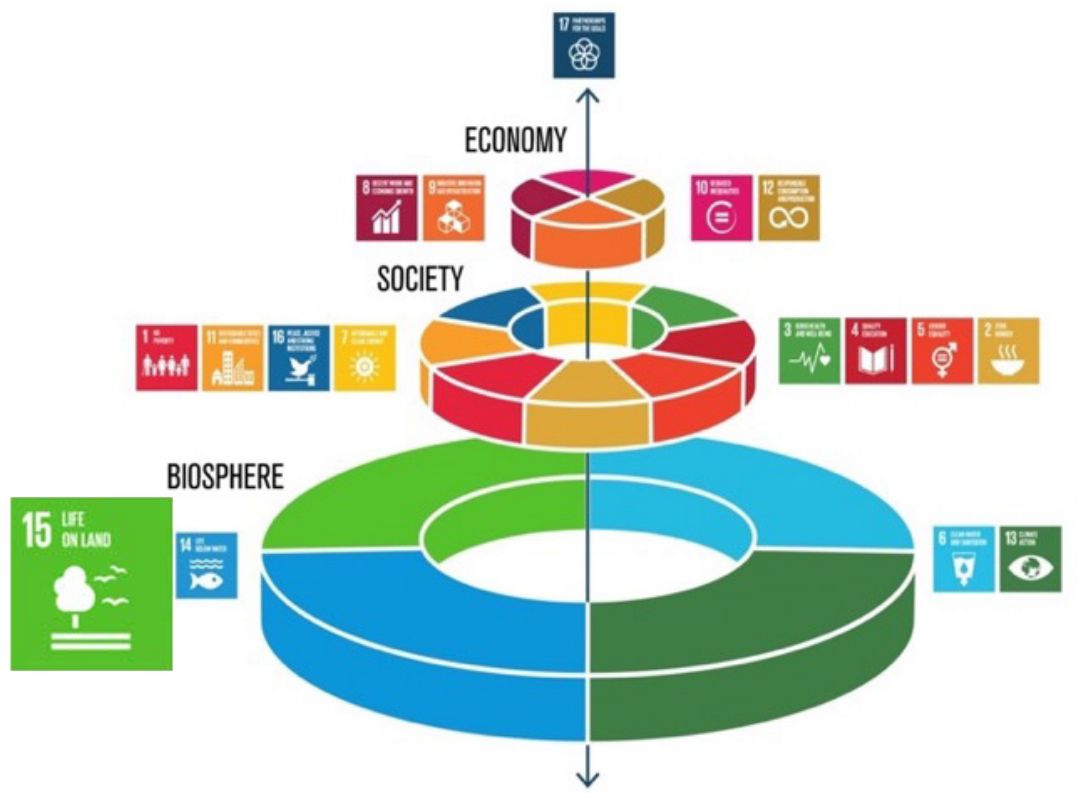

Figure 1 Relation of different domains within the SDGs, Biosphere, Society and Economy (adapted after the original figure of the Azote Images for Stockholm Resilience Centre).

\section{$2.24 / 1000$ initiative}

The Paris Agreement is an agreement within the United Nations Framework Convention on Climate Change (UNFCCC), dealing with greenhouse-gas emissions mitigation, adaptation, and finance, signed in 2016. The Paris Agreement's long-term goal is to keep the increase in global average temperature to well below $2{ }^{\circ} \mathrm{C}$ above pre-industrial levels, and to limit the increase to $1.5^{\circ} \mathrm{C}$, since this would substantially reduce the risks and effects of climate change.

As part of the Paris Agreement, France launched on 1 December 2015 at the COP 21 the international initiative "4 per 1000" (UNFCCC, 2015). The aim of the initiative is to demonstrate that agriculture, and in particular agricultural soils can play a crucial role where food security and climate change are concerned. Supported by solid scientific documentation, this initiative invites all partners to state or implement practical actions on soil carbon storage and the type of practices to achieve this (e.g. agroecology, agroforestry, conservation agriculture, landscape management, etc.). The ambition of the initiative is to encourage stakeholders to transition towards a productive, highly resilient agriculture, based on the appropriate management of lands and soils, creating jobs and incomes hence ensuring sustainable development.

An annual growth rate of $0.4 \%$ in the soil carbon stocks, or $4 \%$ per year, in the upper $30-40 \mathrm{~cm}$ of soil, would substantially reduce the increase in $\mathrm{CO}_{2}$ concentration in the atmosphere related to human activities. This growth rate is not a normative target for each country, but is intended to show that even a small increase in the soil carbon stock (agricultural soils, notably grasslands and pastures, and forest soils) is crucial to improve soil fertility and agricultural production and to contribute to achieving the long-term objective of limiting the temperature increase to the $+2^{\circ} \mathrm{C}$ threshold, beyond which the IPCC (Intergovernmental Panel on Climate Change) indicates that the effects of climate change will be dramatic. The " 4 per 1000 " initiative is intended to complement those necessary efforts to reduce greenhouse gas emissions, globally and generally in the economy as a whole. It is voluntary; it is up to each member to define how they want to contribute to the goals.

In the " 4 per 1000" initiative CA is explicitly mentioned as a farming system that maintains or even increases soil organic matter contents, thereby contributing to climate mitigation. 


\subsection{European Joint Programme on SOIL}

In Europe a large programme on soils is aimed to kick off in February 2020: European Joint Programme SOIL (EJP SOIL). The main objective of EJP SOIL is to create an enabling environment to enhance the contribution of agricultural soils to key societal challenges such as climate change adaptation and mitigation, sustainable agricultural production (food security), protect ecosystem services and land and soil degradation prevention and restoration.

EJP SOIL will build a sustainable European integrated research community on agricultural soils and will develop and deploy a roadmap on climate-smart sustainable agricultural soil management. The roadmap of EJP SOIL is based on a knowledge framework with 4 interacting components: knowledge development set out in project calls with internal and external partners, knowledge sharing $\&$ transfer framed in capacity building for young scientists and in enhancing general public awareness and fostering improved societal understanding and appreciation of agricultural soil management and its contribution to society, knowledge harmonization, storage \& organization addressed at the various levels of the EJP governance to lower barriers to implement harmonised soil information and reporting practices and knowledge application with scientific analyses of (ways to overcome) barriers for adoption of novel practices and technologies in a European context. EJP SOIL actions in interaction with stakeholders, MS's and DG AGRI will foster the long-term goal of promoting farmers as stewards of land and soil resources and to support policy development and deployment. The 6 outcomes include targeted actions and activities in response to societal, scientific, policy and operational challenges. A first annual workplan based on the roadmap is provided as part of the proposal.

The EJP Soil consortium unites a unique group of 27 leading European research institutes and universities in 25 countries.

The provisional roadmap and the knowledge framework that lies at the basis of it will also be used to base the roadmap aimed to be presented at the end of this project for climate smart agricultural soil management in South Africa. The provisional roadmap is available on the following website:

http://dca.au.dk/fileadmin/user_upload/EJP_SOIL_roadmap_final-23-01.pdf

\subsection{CIRCASA}

The CIRCASA (Coordination of International Research Cooperation on soil Carbon Sequestration in Agriculture; https://www.circasa-project.eu/) is a European Project funded under HORIZON 2020. The overarching goal of CIRCASA is to develop international synergies concerning research and knowledge exchange in the field of carbon

sequestration in agricultural soils at European Union and global levels with active engagement of all relevant stakeholders. This includes four specific objectives:

- O1 Strengthen the international research community on soil carbon sequestration in relation to climate change and food security;

- O2 Improve our understanding of agricultural soil carbon sequestration and its potential for climate change mitigation and adaptation and for increasing food production;

- O3 Co-design a strategic research agenda with stakeholders on soil carbon sequestration in agriculture;

- O4 Better structure the international research cooperation in this field.

The project aims to create significant outcomes for the implementation of the UN Sustainable Development Goals (SDGs) and of the Paris agreement (COP21, 4 per 1000 voluntary initiative) of the UN Framework Convention on Climate Change (UNFCCC). 


\section{Methodology}

CIRCASA applies an interdisciplinary and global approach to coordinate international research cooperation in different agricultural systems and pedo-climatic conditions through a strong international partnership.

By bringing together the research community, governments, research agencies, international, national and regional institutions and private stakeholders CIRCASA takes stock of the current understanding of carbon sequestration in agricultural soils, identifies stakeholders' knowledge needs, and fosters the creation of new knowledge.

An Online Collaborative Platform (OCP, still not operational) will structure and integrate existing knowledge in a comprehensive knowledge system on soil carbon in agriculture, delivering a scientific resource of global and local significance (e.g. maps with technical potential for diverse agricultural practices). Active dialogue with stakeholders will be pursued through regular scientific and policy channels and dedicated regional / national stakeholder hubs, gathering their perspectives of SOC sequestration potential, role and management options, barriers and solutions to implementation, and knowledge demands.

Also, in this project a 2020-2025 Strategic Research Agenda (SRA) on agricultural SOC sequestration will be co-designed with stakeholders, grounded on scientific evidence and stakeholders' knowledge demands. The OCP and a range of state-of-the-art information and communication tools will support the communication and outreach strategy. This document is still under revision, however available to the authors of this report. 


\section{Definitions}

\subsection{What is Conservation Agriculture?}

FAO (http://www.fao.org/conservation-agriculture/en/) describes Conservation Agriculture (CA) as a farming system that promotes maintenance of a permanent soil cover, minimum soil disturbance (i.e. no tillage), and diversification of plant species. It enhances biodiversity and natural biological processes above and below the ground surface, which contribute to increased water and nutrient use efficiency and to improved and sustained crop production.

According to FAO Conservation Agriculture is based on the following three principles:

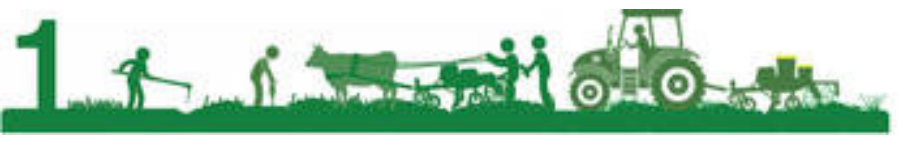

\section{Minimum mechanical soil disturbance}

(i.e. no tillage) through direct seed and/or fertilizer placement.

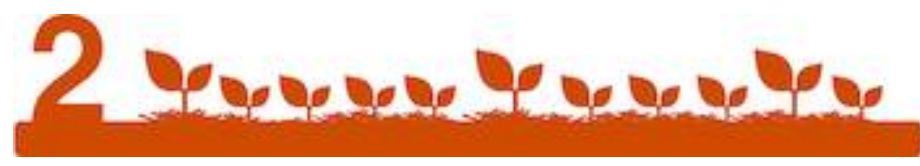

\section{Permanent soil organic cover}

(at least 30 percent) with crop residues and/or cover crops.

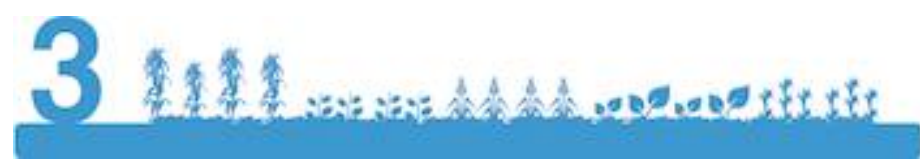

\section{Species diversification}

through varied crop sequences and associations involving at least three different crops.

FAO describes Conservation Agriculture (CA) as a farming system that can prevent losses of arable land while regenerating degraded lands. It promotes maintenance of a permanent soil cover, minimum soil disturbance, and diversification of plant species. It enhances biodiversity and natural biological processes above and below the ground surface, which contribute to increased water and nutrient use efficiency and to improved and sustained crop production.

According to the FAO, CA principles are universally applicable to all agricultural landscapes and land uses with locally adapted practices. Soil interventions such as mechanical soil disturbance are reduced to an absolute minimum or avoided, and external inputs such as agrochemicals and plant nutrients of mineral or organic origin are applied optimally and in ways and quantities that do not interfere with, or disrupt, the biological processes.

CA facilitates good agronomy, such as timely operations, and improves overall land husbandry for rainfed and irrigated production. Complemented by other known good practices, including the use of quality seeds, and integrated pest, nutrient, weed and water management, etc., CA is a base for sustainable agricultural production intensification. It opens increased options for integration of production sectors, such as crop-livestock integration and the integration of trees and pastures into agricultural landscapes. 
In a recent study by Laborde et al. (2020) the drivers for the potential implementation of CA as a viable system for sustainable intensification was assessed globally for a diverse set of agri-ecological and socio-economic landscapes using a machine-learning modelling technique. The study looked at the performance of three rainfed crops: maize, wheat and soybean. The study showed that according to this modelling study, that a combination of climate, soil, geographic and management variables predict the potential of increased yield under Conservation Agriculture. The result showed that in areas with an average temperature of more than 20 degrees $C$ (so humid tropics and sub-tropics) with good plant stand establishment, when implemented for more than 13 years the yield will increase under CA.

\subsection{What is circular agriculture?}

From a broader perspectives circular systems in the blue and green society can be defined as systems in which water, nutrient and carbon cycles are closed and from this, minimize resource loss and climate change effects (Figure 2). Integrated systems, making smart connections between terrestrial production cycles (plant and animal based) and marine production cycles, close and strengthen production cycles and networks to replace linear chains. This knowledge (that partially still is under development) will provide the necessary building blocks of such a circular and climate positive society that ensures climate restoration. This includes efficient use of land, water and energy, carbon sequestration, change in consumer behaviour, as well as the needed governance structures. Efficiently using resources in the food, feed, chemical and materials industry is crucial, while at the same time preventing losses and accumulation of safety hazards when closing loops (after the vision document of KB Circular Systems).

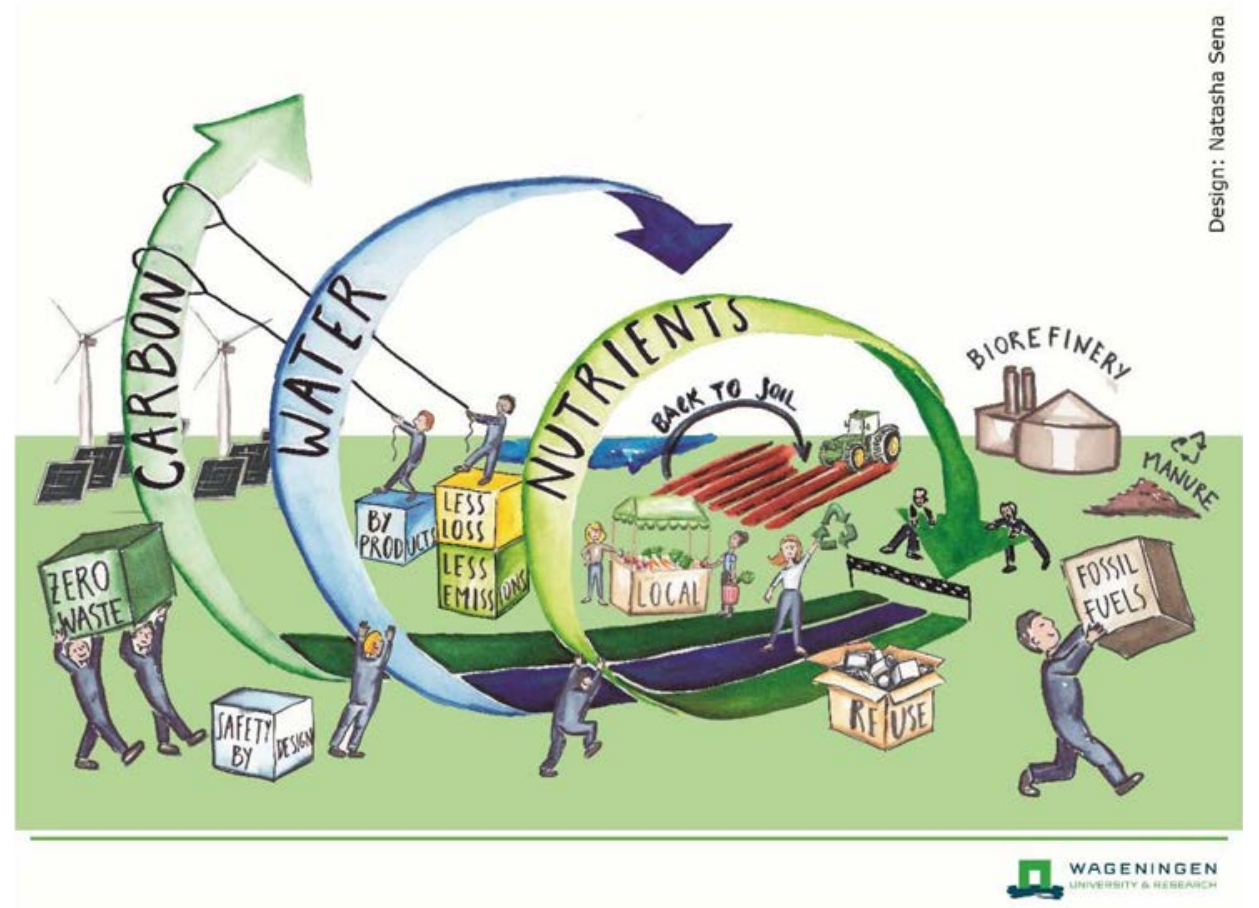

Figure 2 Circular systems in the blue \& green society will close water, nutrient and carbon cycles and minimize resource loss. 
Therefore, circular agriculture is about reducing resource consumption and emissions to the environment by closing the loop of materials and substances. Losses of materials and substances are prevented, and otherwise be recovered for reuse, remanufacturing and recycling. In line with these principles, circular agriculture implies searching for practices and technologies that minimise the input of finite resources, encourage the use of regenerative ones, prevent the leakage of natural resources (e.g. carbon (C), nitrogen ( $N)$, phosphorus (P), water) from the system, and stimulate the reuse and recycling of inevitable resource losses in a way that adds the highest possible value to the system (Jurgilevich et al., 2016).

The circular, climate positive society covers all sectors and systems that rely on biological resources (animals, plants, micro-organisms and derived biomass, including organic waste), their functions and principles. It includes and interlinks: land and marine ecosystems and the services they provide; all primary production sectors that use and produce biological resources (agriculture, forestry, fisheries and aquaculture); and all economic and industrial sectors that use biological resources and processes to produce food, feed, bio-based products, energy and services. To be successful, the European bioeconomy needs to have circularity at its heart and it is necessary to go beyond carbon neutrality. This will drive the renewal of our industries, the modernization of our primary production systems, the protection of the environment and will enhance biodiversity.

Source: adapted from European Commission, A sustainable bioeconomy for Europe: strengthening the connection between economy, society and the environment, October 2018. 


\section{Importance of soil organic matter}

\subsection{Relevance}

Stakeholders from a number of sectors have expressed concern about the decline in organic matter quantity in Dutch arable land. Time series analyses (van den Akker, 2012 and Eurofin Agro, 2017), however, show neither downward nor upward trends on a national level. Locally there may be an ascending or descending soil organic matter quantity, for example when grassland is converted into arable land, or vice versa (Smit et al., 2007). However, the composition and quality of soil organic matter is changing structurally (Eurofins, 2017).

Sufficient soil organic matter is fundamentally important to availability of water and nutrients, trafficability, carbon sequestration, resilience against diseases and plagues and crop production. Maintaining and, where needed, increasing soil organic matter content serves to meet challenges that intensively used agricultural lands face, like dealing with extreme precipitation and drought, both occurring more frequently due to climate change.

That the organic matter content of agricultural fields should increase, has also landed as an issue in politics these days. The Dutch Minister Schouten (Agriculture and Nature) has recently stated in her vision about circular agriculture: "A soil containing much organic matter, is better equipped to absorb water and is more resistant against drought. Such a soil can also retain more nitrogen and minerals, offers a richer soil life and contributes to healthy crops." (Schouten, 2018., p.22). The Soil Strategy, 2016 (in Dutch) of the Soil Technical Commission (TBC) of the Dutch Government indicates specific strategies for managing organic matter on agricultural fields. The draft Climate Accord (Klimaatberaad, 2018) refers to the significance of more organic matter in the soil. 


\subsection{Interactions}

The numerous interactions related to organic matter are shown in Figure 3.

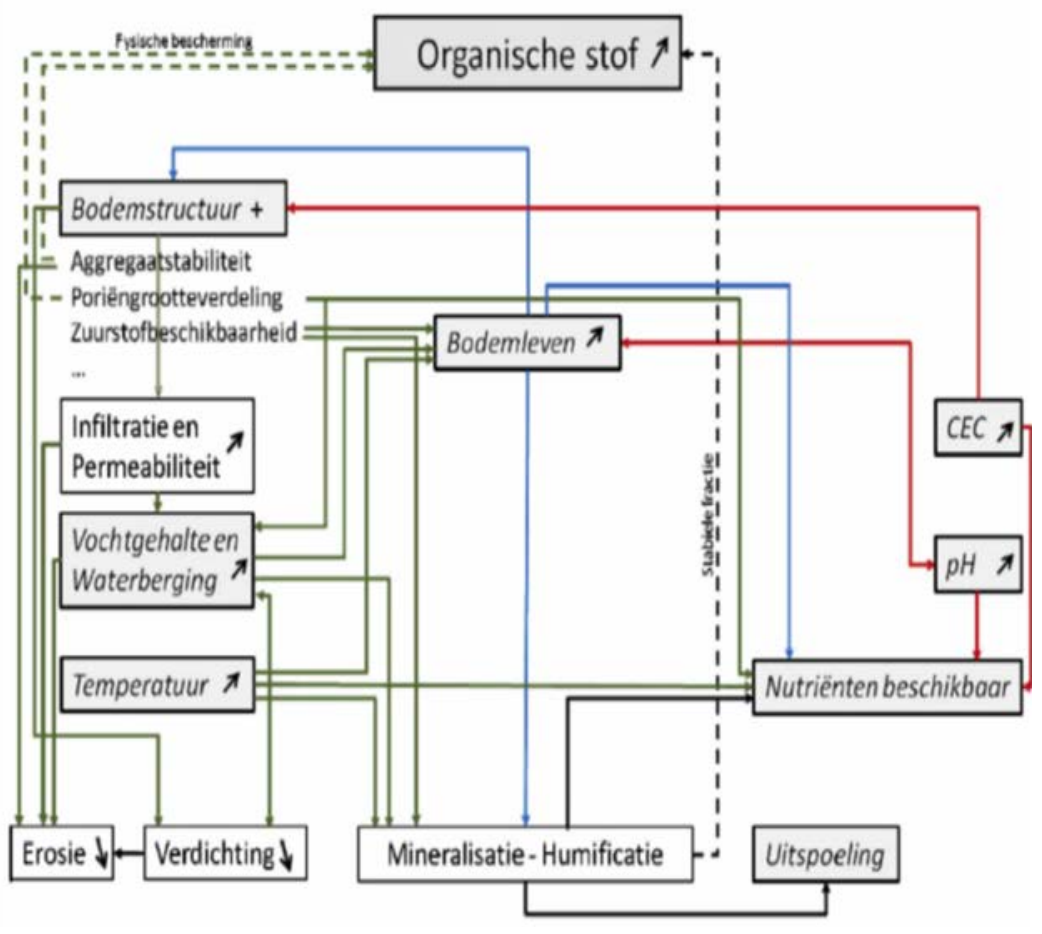

Figure 3 Schematic representation of soil interactions related to organic matter; blue lines: effect of soil life; green arrows: soil physical effects; red lines: soil chemical effects; dark lines: effects of soil processes. Dash lines: correlation with organic matter. Source: Reubens et al., 2010.

\section{Organic matter, nutrient availability and soil structure}

The influence of the quantity of soil organic matter on the nutrient balance is complex. An increase of the organic matter content leads to a stronger soil bonding of nutrients due to a higher cationexchange capacity (CEC). When organic matter is decomposing, nutrients become available, so less fertiliser will suffice. However, in case nutrients are released in a period in which the crop does not require them, a higher organic matter content may lead to larger nutrient losses to ground and surface water. Generally, clay soils have a good inherent soil fertility. Sandy soils strongly depend on organic matter for nutrient supply. In these soils availability of nutrients is largely determined by interactions between soil life and soil organic matter.

There is a clear correlation between organic matter content and soil structure (Faber et al., 2011). The more organic matter present, the better soil structure will be. A good soil structure is essential for the carrying capacity and infiltration capacity, it limits the sensitivity for sealing and the chance of soil compaction, it makes the soil less sensitive for soil diseases and gives a higher crop yield.

\section{Organic matter and water availability}

The influence of the quantity of organic matter on water availability may be exerted directly or indirectly.

Direct effect on water retention

A direct effect is the influence of organic matter on the water retention. The water availability of the soil is calculated, by multiplying the quantity of available water between field capacity at $\mathrm{pF}=2$ and wilting point at $p F=4.2$, with the thickness of the root zone $\Delta z$, like indicated in Figure 4 . 


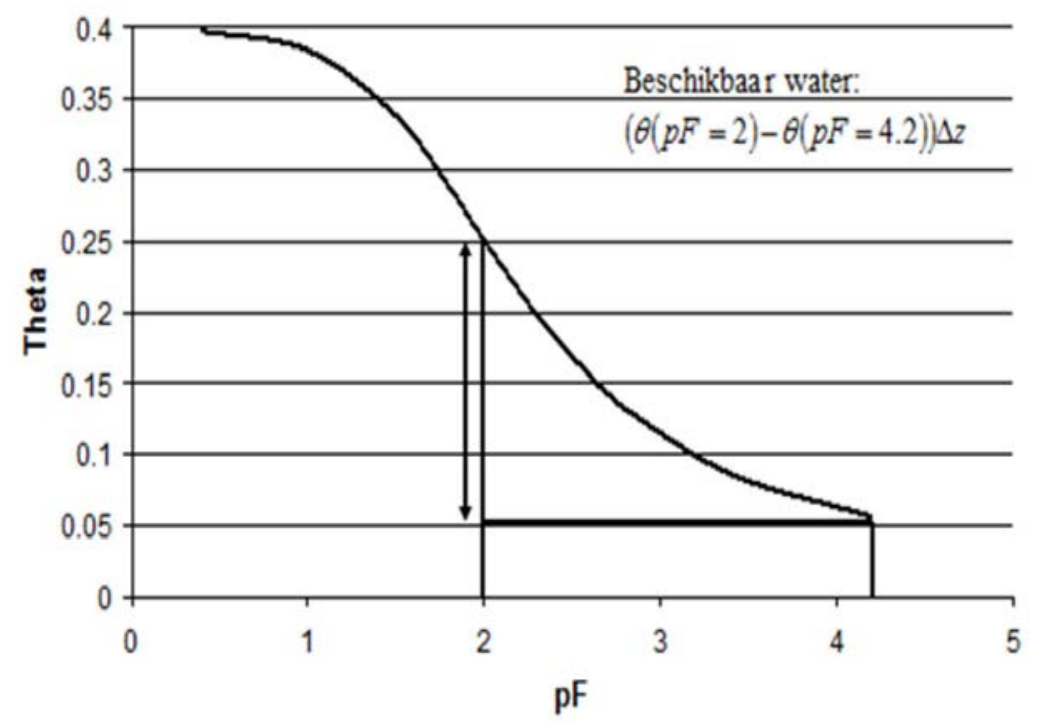

Figure 4 Water retention characteristic indicating the relationship between the pressure head ( $p F$ value) and the corresponding volumetric moisture content (Theta).

Derived from information about sandy soils in the Staring series (Wösten et al., 2001), the relation is calculated between the organic matter content and moisture content when saturated, at pF 2 (field capacity) and at pF 4.2 (wilting point). Figure 2 shows the result of calculations for a sandy soil and indicates that moisture content at all 3 pressure heads increases with increasing organic matter contents.

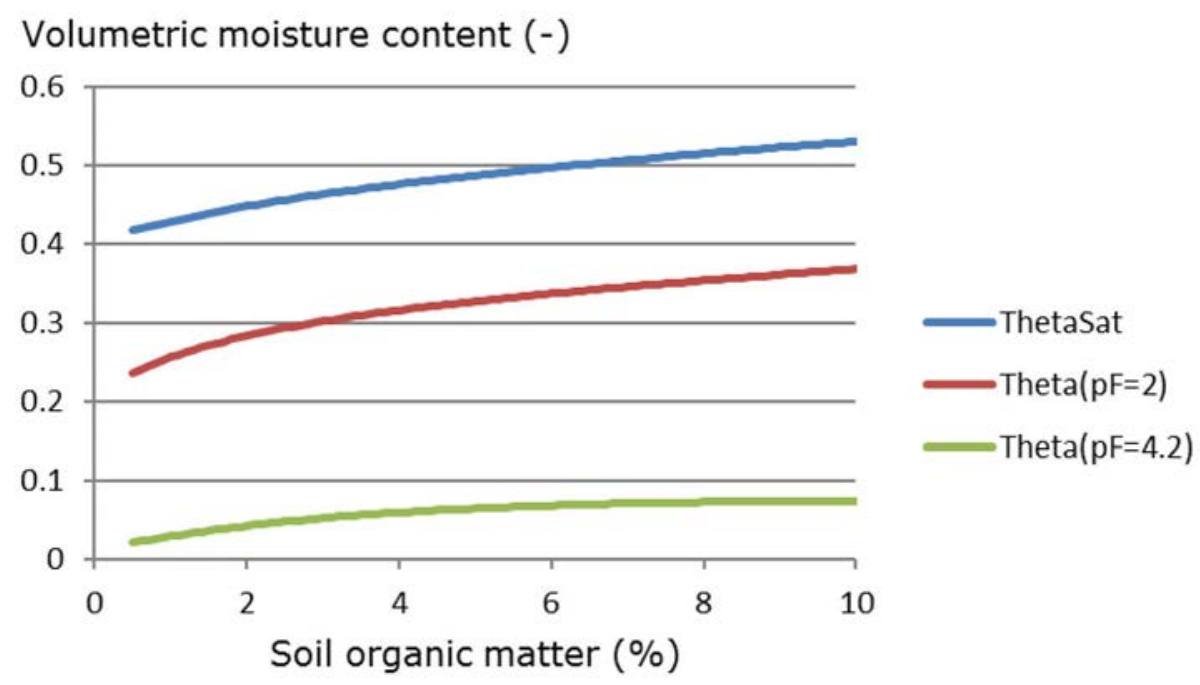

Figure 5 Curve of the volumetric moisture content at saturation, at pF 2 (field capacity) and at 4.2 (wilting point) with organic matter content.

Taking Figure 5 as the starting point, Figure 6 gives the increase of the water availability with increasing organic matter contents.

Since the sandy soils from the Staringreeks (Wösten et al., 2001) contain minimally $1 \%$ organic matter, increase in water availability (Figure 6) is an estimation. In case organic matter contents are below $1 \%$, these are shown, for this reason, as dotted lines. 


\section{Available moisture in a $10 \mathrm{~cm}$ soil layer $(\mathrm{mm})$}

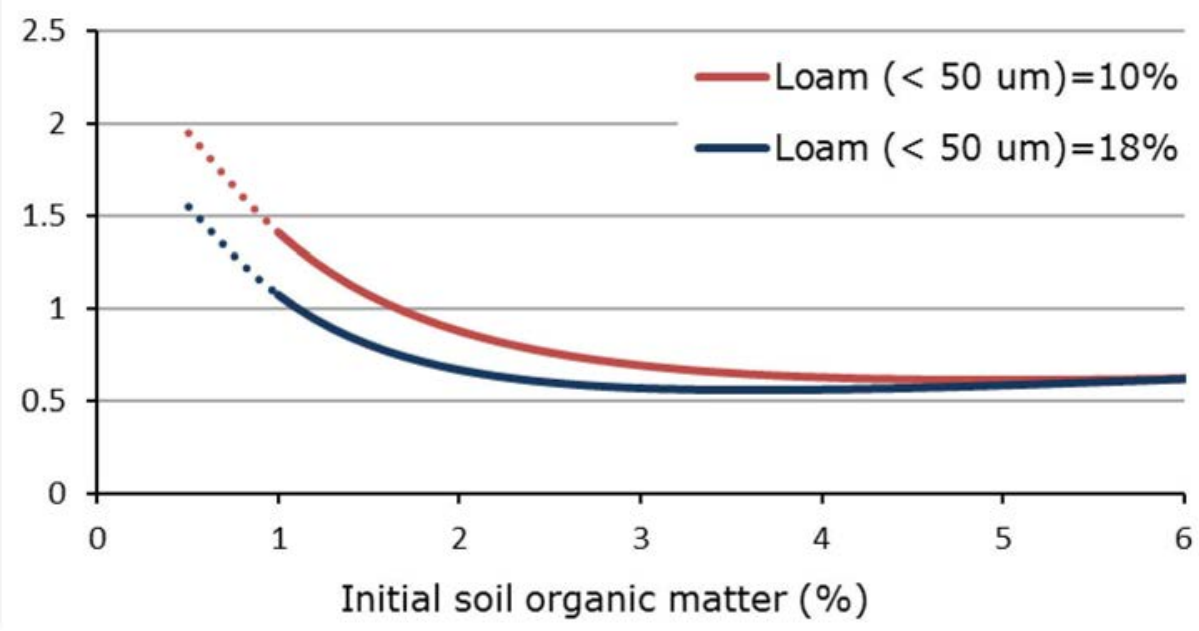

Figure 6 Increase of water availability $(\mathrm{mm})$ in a layer of $10 \mathrm{~cm}$ with an increase of organic matter of $1 \%$.

Indirect effect on water retention

An indirect effect of organic matter is a lowering of the bulk density of soils and therefore the resistance against penetration by plant roots. Plants on soils with higher organic matter contents may not only take up more water from a certain root zone, but this root zone can also become thicker, making again more water available.

The most important conclusions in relation to organic matter content and water availability are:

- An increase of organic matter content leads to a direct and indirect increase in water availability. The indirect effect has not been quantified.

- Poor sandy soils with 0,5 up to $1 \%$ organic matter will render, with an increase of $1 \%$ organic matter, an increase of $3-4 \mathrm{~mm}$ available water (Figure 6) in a root zone with a thickness of $20 \mathrm{~cm}$. This roughly equals one day extra transpiration.

- In the trajectory from 1 to $3 \%$ organic matter, an increase of $1 \%$ organic matter leads to an increase of $2-3 \mathrm{~mm}$ available water (Figure 6 ) in a root zone of $20 \mathrm{~cm}$ this equals less than one day extra transpiration.

- In the trajectory from $>3 \%$ organic matter, an increase of $1 \%$ organic matter leads to an increase of $1 \mathrm{~mm}$ available water in a root zone of $20 \mathrm{~cm}$ (sand).

- In a dry summer, in which the precipitation deficit continuously increases, extra water availability will have little effect. However, in a moderately dry summer with a regular shower, extra water availability of 3-4 $\mathrm{mm}$ can be used multiple times and it could lead to postponing a sprinkler irrigation application of $20-25 \mathrm{~mm}$ or to not apply this at all.

- The more organic matter is present, the better the soil structure, thereby giving the soil a higher infiltration capacity with less ground level run-off (indirect positive effect on the water retention and possibly reduction of peak discharges (Schipper et al., 2015). Also the composition and the ratio between dynamic and stable organic matter can have an influence on the water retention (Eurofins, 2017). No field studies are known, that quantify these indirect effects for Dutch soils, yet there are indications from field research elsewhere (Williams et al., 2017), that point to a positive effect.

- A good soil structure makes it possible that plants root well, which means increasing water availability for the crops. Based on an average of $25 \%$ available water (Figure 5), a root zone of $20 \mathrm{~cm}$ renders $50 \mathrm{~mm}$ water. With a root zone of $30 \mathrm{~cm}$ this is $75 \mathrm{~mm}$. This means an increase of $50 \%$. 


\section{$5 \quad$ Effect of soil organic matter on crop yield}

A meta-analysis by Hijbeek et al. (2017) using data from 20 long-term experiments in Europe, showed that across all experiments, the mean additional yield effect of organic inputs was not significant $(+1.4 \% \pm 1.6$ ( $95 \%$ confidence interval). In specific cases however, especially for root and tuber crops, spring sown cereals, or for very sandy soils or wet climates, organic inputs did increase attainable yields. This conclusion was somewhat surprising because organic inputs do have a positive effects on the soil organic matter balance and as such they are an important asset for soil fertility and crop growth. The authors conclude that "using organic inputs to increase soil organic matter is often seen as a win-win situation for food security and climate change mitigation, such as the recently proposed " 4/1000 initiative" at COP21 (UNFCCC, 2015). Using organic inputs to sequester carbon might be a viable option to buy time for developing technologies for reducing industrial emissions (IGBP, 1998), this meta-analysis however shows that benefits for crop yields cannot be assumed to follow directly".

A statistical analysis of databases with soil data shows a non-significant relationship between soil organic matter content and infiltration capacity of the soil (Rahmati et al., 2018). However, farming systems research with different forms of long-term organic matter management in traditional and biological agriculture shows that the infiltration capacity of the soil increases with an increase in soil organic matter content (Williams et al., 2017). As a result, the effect of soil organic matter on crop yield is mostly not direct but rather indirect by means of increased nutrient and water availability. 


\section{Effect of soil organic matter on climate mitigation}

To mitigate climate change there is the option of using 'negative emissions technologies' - methods that remove $\mathrm{CO}_{2}$ from the atmosphere. Soil organic carbon (SOC) sequestration is a major mitigation option. Two to three times more carbon is stored in soil organic matter than in atmospheric $\mathrm{CO}_{2}$ (IPCC, 2013). Up to $1.4 \mathrm{Gt} \mathrm{C}$ could be stored annually in agricultural soils (IPCC, 2007, 2014). SOC sequestration is among the cheapest methods with the greatest potential. It requires conserving carbon stocks, storing carbon in agricultural landscapes both in soil organic matter and in biomass through agroforestry, reducing $\mathrm{CO}_{2}$ emissions from drained peatlands and wetlands and better recycling organic carbon through improved circularity and lifecycle of urban and agri-food industries organic wastes, thereby contributing to the bio-economy. Soil carbon sequestration could even reach to absorb one-third of the annual increase in atmospheric $\mathrm{CO}_{2}$-carbon, however, the duration of the effect would be limited, with significant impacts lasting only 20-50 years. Carbon sequestration in soils may form in the future a key technology to mitigate climate change (Smith, 2004, Roe et al., 2019). International agreements, such as the Kyoto Protocol and the Paris Agreement encourage soil carbon sequestration and could be used to formulate soil carbon sequestration polices. However, other environmental impacts as well as political, economic and societal needs, need to be taken into account in order to ensure sustainable development.

The concentration of organic carbon in soil is regulated by the relative rates of organic carbon addition and loss. In natural soils across the earth, these rates are generally controlled by average annual temperature and average annual precipitation. At a smaller scale, other factors heavily influence soil organic carbon content. By understanding the processes controlling organic carbon cycling in soils we can better predict effective and efficient land use and management practices for increasing agricultural soil organic carbon. The actual environmental setting will be definitive to decide the best agricultural practice to increase soil carbon concentrations as new organic carbon is introduced to soils via plant activity. Simply, atmospheric carbon fixed via photosynthesis is transferred to the soil by plant exudates and plant organic matter degradation. This organic carbon is either respired and released as $\mathrm{CO}_{2}$ (mineralised) or stabilised, e.g. in association with soil particles.

Approximately $12 \%$ of earth's land surface is classed as arable by the Food and Agriculture Organization of the United Nations (FAO), and 38\% classed as Agricultural (excluding land used for wood/timber production). For effective agricultural land management to maximise soil organic carbon, current and reliable data is needed on soil parameters. This requires improved soil monitoring and management across the globe. To be able to assess this, well-established monitoring methods need to be developed. Changes in soil carbon are small compared to the large stocks of carbon present in the soil, meaning that changes can be difficult to measure. Soil organic carbon monitoring requires the accurate measurement of a number of other soil parameters, which is not trivial.

In a paper by Smith et al., 2019 the role of soil carbon sequestration was highlighted for how it contributes to the various NCP (Natures Contribution to People) and the land and soil related SDGs. In chapter 7 different ways to increase soil carbon in agricultural soils. However, also in other land use types such as grazing land and forests carbon can be sequestered in soils. Practices that increase soil organic matter content include a) land use change to an ecosystem with higher equilibrium soil carbon levels, b) management of vegetation: including high input carbon practices, e. g. improved rotations, cover crops, perennial cropping systems, c) nutrient management to increase plant carbon returns to the soil, e.g. through optimised fertiliser application rate, type, timing and precision application, d) reduced tillage intensity and residue retention, and e) improved water management: including irrigation in arid conditions (Smith, 2019). In Figure 7 published in Smith et al., 2019 it is depicted how SCS can impact upon soil functions, NCPs and the SDGs. 


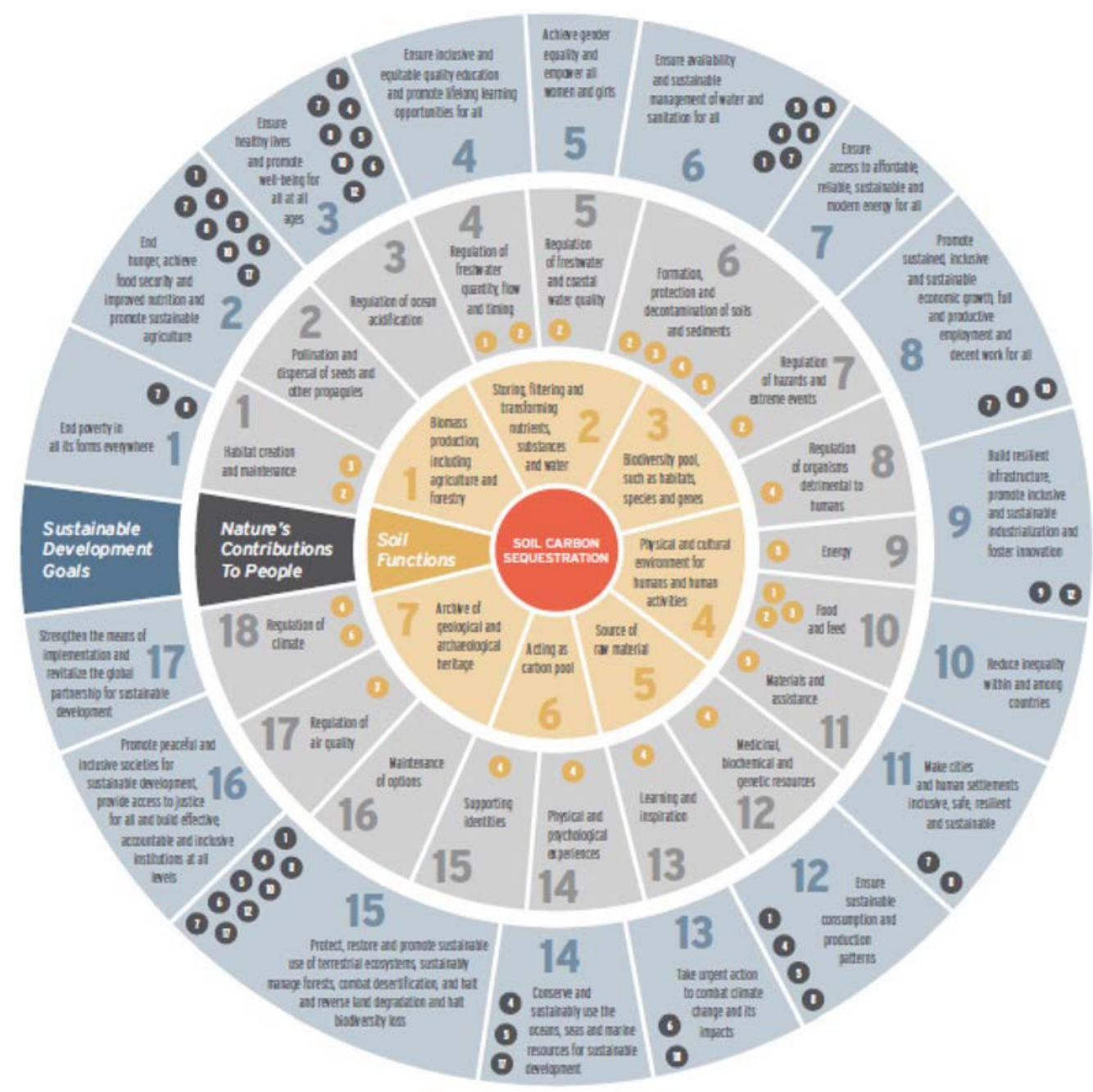

Figure 7 Summary of the impact of SCS on soil functions, on NCPS and on the SDGs, showing the contribution to the SDGs from each soil function and NCP impacted by SCS (after Smith et al., 2019).

What we can see in this figure are some clear links to how storing more carbon in soils (SDG 13) cannot be achieved alone. Climate Action is supported by carbon storage by creating a large (but potentially reversible) sink for atmospheric $\mathrm{CO}_{2}$, and improved resilience to climate change (e.g. $41,45)$. But to do this solely for the sake of climate mitigation, this will not be feasible from a socioeconomic point of view. If measures as described above are implemented for carbon storage this will have a positive effect on several other SDGs: Prevention of erosion and polluted substances from reaching water bodies will help Life below water (SDG14). Improved soil health will be beneficial for SDG 15, Life on land, which will in turn enhance biodiversity and healthy ecosystems. Furthermore, soil health will improve clean water and sanitation (SDG 8), make agriculture more resilient (see chapter 5) to droughts, thereby helping towards SDG2 No poverty and Zero Hunger (Lal et al., 2016; Keesstra et al., 2016). 


\section{Ways to increase organic matter content}

It is important to note some general limitations to storing more carbon in agricultural soils. Firstly, there is a maximum or equilibrium amount of carbon that can be stored in stable form attached to soil aggregates for the long-term. This is different for specific soil types and characteristics and limits the carbon sequestration potential of agricultural soils already within 20 years (King et al., 2018; Weiske, 2007). It is important to consider that increasing SOC is a long-term process in which the benefits only become visible after many years, whereas the cost will arise every year. Also, nitrogen availability can become a limiting factor, since organic matter has a specific $\mathrm{C} / \mathrm{N}$ ratio. When only adding carbon, there will be a nitrogen shortage that limits further organic matter production by plants and thereby uptake of carbon in soils. Moreover, the critical $C$ input to maintain current $C$ stocks is positively related to the amount of the current $C$ stock (Wang et al., 2016). This basically means that a higher SOC level requires higher annual SOC inputs. Also microbial decomposition rates increase with rising temperatures and therefore, due to climate change, carbon storage can become increasingly difficult (M. Hagens, personal communication, October 7, 2019). For these reasons, enhancing carbon uptake by soils can only be a temporary solution for offsetting the increase in atmospheric greenhouse gas emissions. First of all, it is important to quantify what an increase of 1 - $5 \%$ organic matter means in terms of the yearly supply of organic matter. It is important hereby, to make a distinction between two forms of organic matter: old organic matter ("humus") that degrades at a rate of $2 \%$ under Dutch circumstances, and fresh organic matter of which $40 \%$ is converted into humus within one year. Kortleven (1963) provides a calculation scheme for the accumulation and decay of soil organic matter:

$\mathrm{H}=\mathrm{H}_{\mathrm{E}}+\left(\mathrm{H}_{0}-\mathrm{H}_{\mathrm{E}}\right) \exp (-\alpha \mathrm{t})$

Where:

$H_{E}$ is the equilibrium value of humus:

$\mathrm{H}_{\mathrm{E}}=\mathrm{pI} / \alpha, \mathrm{p}=$ the transformation fraction of fresh organic matter $\left(0.4 \mathrm{y}^{-1}\right)$

$\alpha=$ decomposition speed humus $\left(0.02 \mathrm{y}^{-1}\right)$

$\mathrm{I}=$ annual input fresh organic matter $\left(\mathrm{kg} \mathrm{ha}^{-1} \mathrm{y}^{-1}\right)$

$\mathrm{H}_{0}=$ initial amount of humus $\left(\mathrm{kg} \mathrm{ha}^{-1}\right)$

Fresh organic matter is superficially supplied and subsequently ploughed through. Conversions will then take place in the $20-25 \mathrm{~cm}$ thick root zone. Such a root zone corresponds with ca $3106 \mathrm{~kg}$ soil / ha and $1 \%$ increase of this is $3104 \mathrm{~kg}$ organic matter ha-1. The yearly supply would then amount to $0.02 * 3104 / 0.4=1,500 \mathrm{~kg}$ fresh organic matter per hectare, which is quite a significant volume. This is why it is more practical to follow a long-term strategy, instead of aiming to reach this $1 \%$ increase in 1 year. The strategy would then be to increase the organic matter content by $1 \%$ gradually, over several years.

The soil organic matter content, in general, can be raised in the following 3 ways (SmartSoil project, 2015):

1. Advancement of input in the soil of crop- and root residues

2. Increase of the quantity of soil organic matter by supplying manure and compost (both from external sources as from the farm itself)

3. Reduction of de-composting losses by limiting disturbance of the soil

The following cultivation measures have a positive effect on conserving and increasing of the soil organic matter content:

\section{- Crop rotation}

Cultivation of crops with a long growing season combined with the cultivation of leguminous plants that improve the quality of organic matter.

\section{- Crop residues}

Crop residues are those materials that are left on the field after the crop has been harvested. This includes stems, stubbles, leaves, roots and chaff. Insert these crop residues maximally into the soil. 


\section{- Supply of manure and compost}

Supply of manure and compost effectively enhances the organic matter content, because it decomposes less quickly than fresh crop- and root residues. Supplying manure and compost will also often decrease the necessity to apply fertiliser.

\section{- Soil covering and catchment crops}

Prevention of fallowing in winter, by cultivating crops year-round, enhances the insertion of organic matter and decreases soil erosion and leaching of nutrients.

\section{- Conservation agriculture}

Conservation agriculture consists of minimizing soil tillage and having permanent soil coverage and diversity in crops. Minimal- and eventually no soil tillage, by a transition from frequent ploughing to forms of non-inversion tillage, diminishes the decomposition of organic matter.

The five measures are summarised in Table 1. Both the prevention of fallowing and the reduction of tillage take time before it results in an obvious increase of organic matter content.

Table 1 Promising measures for the increase of organic matter content and their most important characteristics in the short ( $0-5$ years), medium (5 - 10 years) and long ( $>10$ years) term.

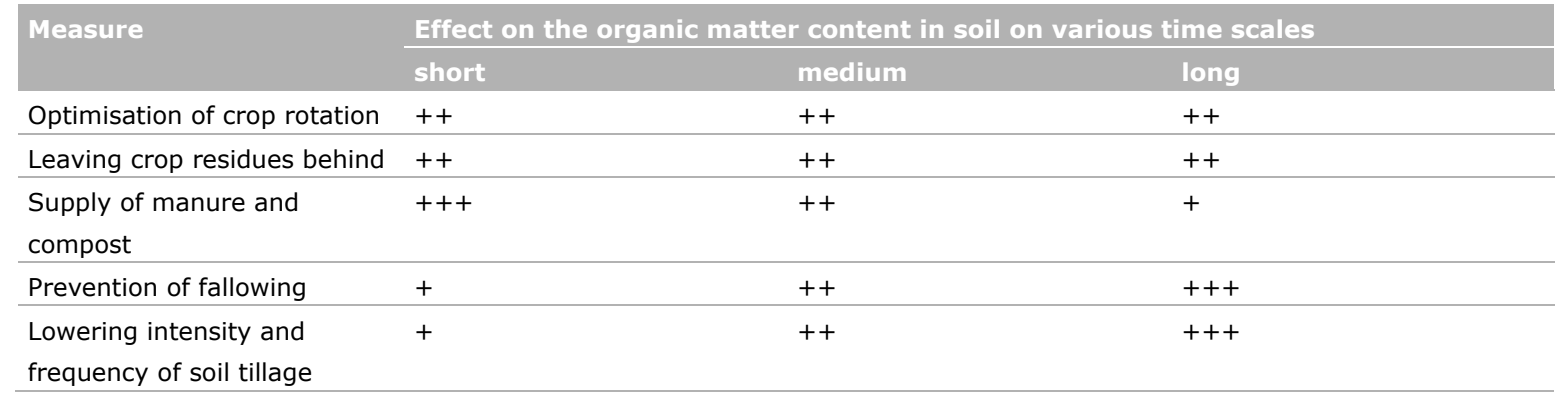




\section{The South African Context}

\subsection{Soil organic carbon status of soils in Southern Africa}

Soil organic carbon (SOC) in much of Africa is lower than in the temperate climates (Figure 8 ) due to warm temperatures and abundant rainfall resulting in high rates of decomposition of organic matter. In South Africa, Du Preez et al. (2011) reported that $58 \%$ of soils have less than $0.5 \%$ OC while Schütte et al. (2019) in a recent mapping of organic C in soils found that only $3.2 \%$ of surveyed terrain units had soils with $\geq 2 \%$ OC levels. The majority of soils sampled during validation on-farm trials in Malawi, Mozambique, Zambia and Zimbabwe had C concentration below $11 \mathrm{~g} \mathrm{~kg}^{-1}$ which is below the critical level required to sustain crop production and avoid soil degradation (UNCCD, 2015; Cheesman et al., 2016).

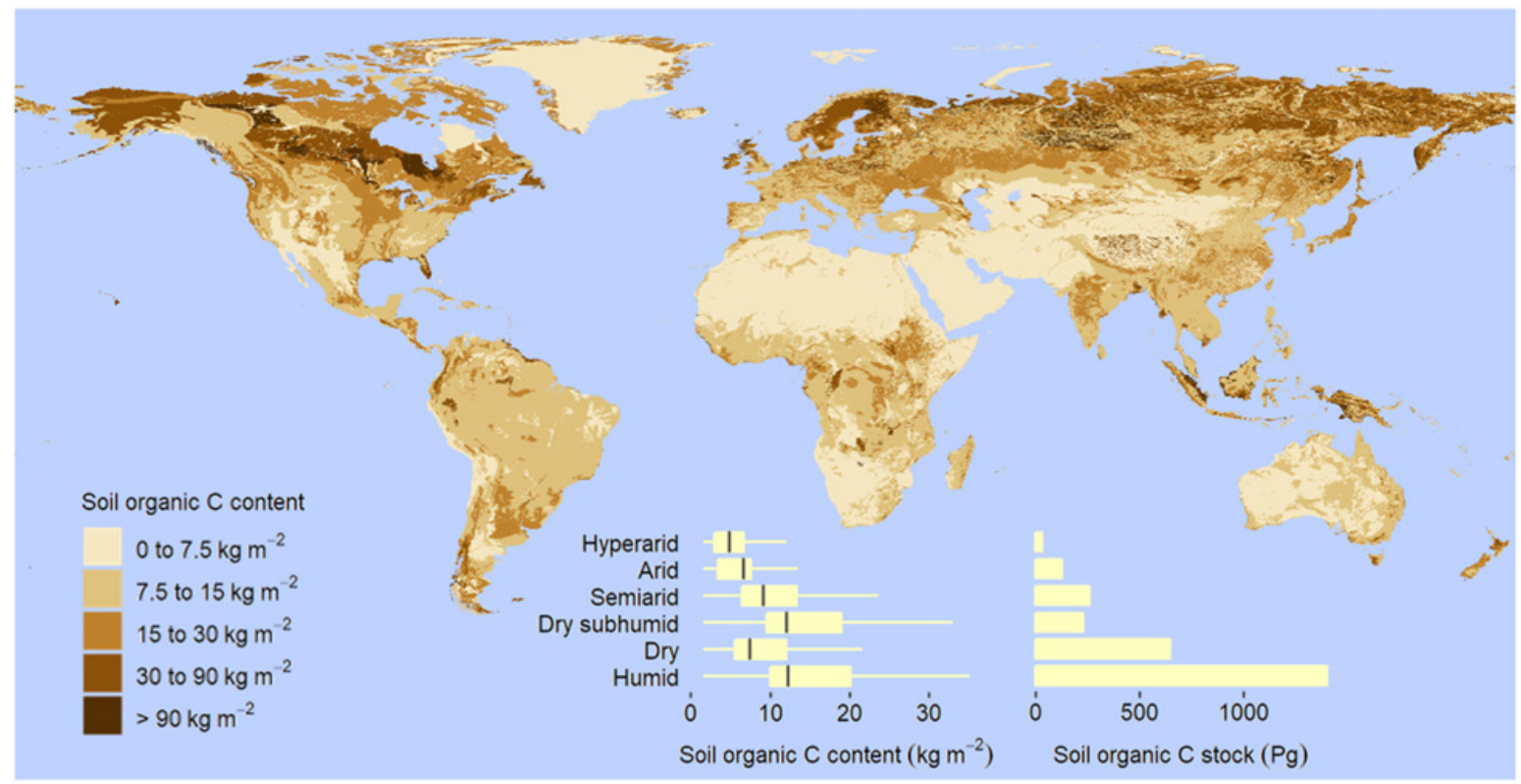

Figure 8 Distribution of soil organic carbon to one metre depth (USDA Natural Resources Conservation Service, 2006).

A number of management practices have contributed to the decline in SOC across farming systems in the region. About $46 \%$ loss of SOC in South Africa was attributed to cultivation by Swanepoel et al. (2016) as tillage results in increased decomposition of organic matter. Under smallholder agriculture, additional contributory factors to SOC depletion are reduced net primary production, the low amounts of $\mathrm{C}$ inputs added to the soil and by poor land management practices that result in erosion of the top soil (Corbeels et al., 2019). The low SOC stocks in African soils present an opportunity for the soils to become $\mathrm{C}$ sinks through the use of management practices that can increase soil $\mathrm{C}$ inputs and / or reduce top soil erosion and increase crop productivity. This sequestering of $C$ by soils can reduce the amount of $\mathrm{CO}_{2}$ released into the atmosphere and thus contribute to mitigate increasing concentrations of greenhouse gas emissions. Among management practices that reduce $\mathrm{C}$ loss are erosion control, reduced / no tillage and use of cover crops while increasing $C$ input can be achieved through addition of compost, manure and crop residues to soils. Conservation agriculture (CA), comprising the simultaneous application of continuous no or minimum mechanical soil disturbance; permanent soil mulch cover and crop diversification, has been identified as one of the feasible and sustainable means to increase C stocks in the soil (Corbeels et al., 2019; Gonzalez-Sanchez et al., 2019). 


\subsection{Conservation agriculture in Southern Africa}

The worldwide promotion of CA in recent decades has resulted in an observed $69 \%$ (global) and $211 \%$ (Africa) increase in area under where all three CA principles were practiced between 2008 and 2016 (Kassam et al. 2018). In in Southern Africa, there was a $214 \%$ in area under CA over the same period with the greatest increases observed in Malawi and Mozambique (Table 2). There is still potential for further adoption of CA in the region if locally suitable solutions are found to challenges such as high labour requirements for manual tillage and weed management systems, competition for crop residues especially in semi-arid areas, cover cropping, integration of livestock and availability of markets for legume and other non-maize crops.

Table 2 Extent of adoption of conservation agriculture in Southern Africa by country in 2008/09, 2013/14 and 2015/16 (Adapted from Kassam et al., 2018).

\begin{tabular}{|c|c|c|c|}
\hline \multirow[t]{2}{*}{ Country } & \multicolumn{3}{|c|}{ CA area ('000 ha) } \\
\hline & $2008 / 09$ & $2013 / 14$ & $2015 / 16$ \\
\hline South Africa & 368 & $368^{*}$ & 439 \\
\hline Zimbabwe & 15 & 90 & 100 \\
\hline Mozambique & 9 & 152 & 289 \\
\hline Malawi & - & 6.5 & 211 \\
\hline Namibia & - & 0.34 & $0.34^{*}$ \\
\hline Southern African total & 432 & 819 & 1357 \\
\hline Global total & 106505 & 156739 & 180439 \\
\hline
\end{tabular}

* Taken from previous period

Gonzalez-Sanchez et al. (2019) estimated C sequestered under CA croplands in Africa was estimated at $1543022 \mathrm{Mg} \mathrm{C}$ year $^{-1}$ of which $89 \%$ was from Southern Africa (Table 3). If the area was expanded to all areas suitable for CA in Africa, this figure would increase by 93 times highlighting the potential of African soils to mitigate climate change through reductions in emission of $\mathrm{CO}_{2}$.

Table 3 Current SOC fixed annually by CA croplands compared to conventional tillage based agriculture in Africa (Gonzalez-Sanchez et al., 2019).

\begin{tabular}{|c|c|c|c|c|}
\hline Country & $\begin{array}{l}\text { No-tillage } \\
\text { adoption }{ }^{\infty} \text {, ha }\end{array}$ & $\begin{array}{l}\text { C sequestration in no- } \\
\text { tillage }\left(\mathrm{Mg} \mathrm{ha}^{-1} \mathrm{yr}^{-1}\right)\end{array}$ & $\begin{array}{l}\text { Current annual C } \\
\text { sequestration } \mathbf{M g ~} \mathrm{yr}^{-1}\end{array}$ & Climatic zone \\
\hline Algeria & 5600 & 0.44 & 2464 & Mediterranean \\
\hline Kenya & 33100 & 1.02 & 33762 & Tropical \\
\hline Lesotho & 2000 & 1.02 & 2040 & Tropical \\
\hline Malawi & 211000 & 1.02 & 215220 & Tropical \\
\hline Morocco & 10500 & 0.44 & 4620 & Mediterranean \\
\hline Mozambique & 289000 & 1.02 & 294780 & Tropical \\
\hline Namibia & 340 & 0.50 & 170 & Sahel \\
\hline Tanzania & 32600 & 1.02 & 33252 & Tropical \\
\hline Tunisia & 12000 & 0.44 & 5280 & Mediterranean \\
\hline Uganda & 7800 & 1.56 & 12168 & Equatorial \\
\hline Zambia & 316000 & 1.02 & 322320 & Tropical \\
\hline Zimbabwe & 100000 & 1.02 & 102000 & Tropical \\
\hline TOTAL & 1509240 & & 1543022 & \\
\hline
\end{tabular}

œ Source: Kassam et al., 2018, countries from Southern Africa italicized 


\subsection{Studies on CA impacting SOC in Southern Africa}

The effect of CA on soil $\mathrm{C}$ in Southern Africa presents a mixed bag with increases, no effect and decreases in SOC reported, but on closer inspection it is noted that when all the three principles of CA are applied SOC is often seen to increase (Table 4). Therefore, the potential $C$ sequestration benefits under CA seem to accrue when minimum tillage is practice in tandem with crop residue mulching / provision of soil cover and diversified cropping systems. In most of the studies $\mathrm{SOC}$ is low and does not reach the $11 \mathrm{~g} \mathrm{~kg}^{-1}$ limit even after several years under CA. Aune and Lal (1997) give $11 \mathrm{~g} \mathrm{C} \mathrm{kg}^{-1}$ as the critical limit that would allow supporting of crop productions in most tropical soils. This highlights that the level of $C$ inputs particularly under smallholder agriculture and / or semi-arid area is too low to substantially change soil $C$ concentration in the short and long term. Research also pointed to differences across seasons and soil types which also need to be considered. From this preliminary review, our findings are in agreements with those of Corbeels et al. (2019) that African soils have a large potential to act as sinks for $C$ and $C A$ is one strategy to achieve this. However, the need for adoption of all three CA principles for maximum benefits to be realized that reflects findings for weed suppression (Mashingaidze et al., 2017), soil improvements and yield benefits (Rusinamhodzi et al., 2012) may reduce the potential of CA to store $C$ in crop lands in Southern Africa and much of Sub-Saharan Africa. This is because a large majority of smallholder farmers whose soils would get the most benefits from CA mostly adopt minimum tillage with limited crop residue mulching and crop diversification (Findlater, 2015; Pedzisa et al., 2015; Giller et al., 2009).

In conclusion, although $\mathrm{C}$ soil sequestration can be physically achievable on farms in Southern Africa and elsewhere, Amundson and Biardeau (2018) view the current targets for $C$ sequestration by agricultural soils in literature and 4 per $1000 \mathrm{goal}$ as too optimistic and unlikely to be achieved in reality. This is because the focus so far has been on the natural science aspects but now there is need going forward for social research to identify and address the economic and political barriers to adoption of proposed climate smart technologies such as CA by farmers. Policies that incentivise the adoption of these practices and /or compensate farmers for transaction costs and risks associated with a change in farming practices are key. 


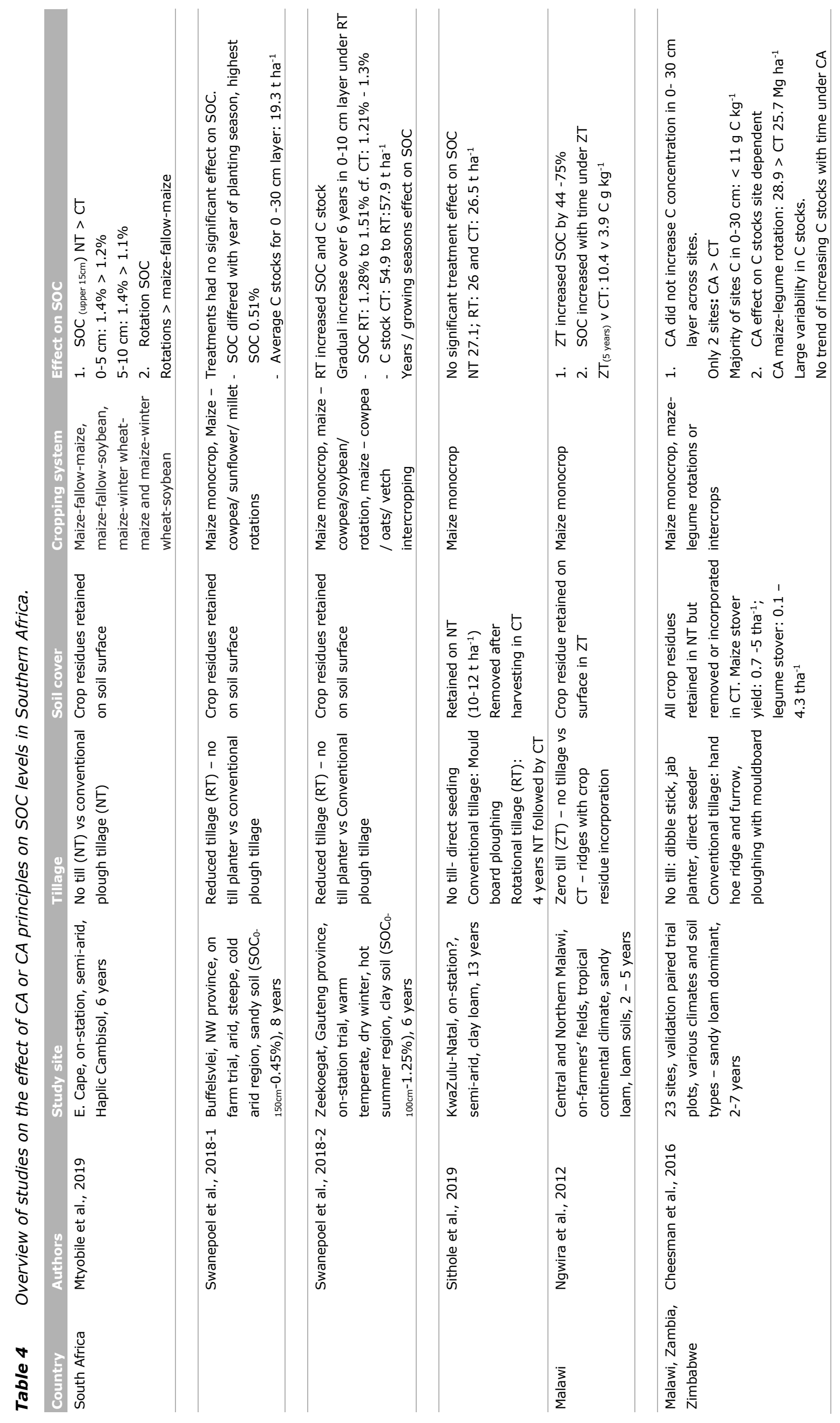




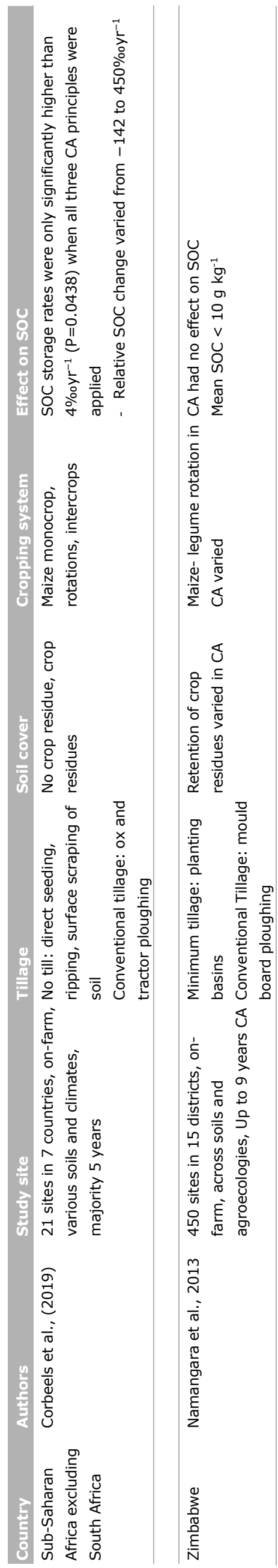

Wageningen Environmental Research report 3024| 31 


\subsection{Enabling conditions for sustainable agricultural management in South Africa}

During the workshop we discussed the following topics to assess the barriers and enabling conditions in South Africa to work towards sustainable agricultural management. Essential issues to address when thinking about the future implementation of CA are:

- Which knowledge is missing?

- Which knowledge does not exist?

- Which knowledge is not integrated enough?

- What are the benefits of soil carbon and soil quality in general for both agricultural productivity and resource efficiency, especially at low soil C levels $(<1 \%)$.

- Uncertainty about the efficacy of measures and return on investment in soil management.

- Is the transfer of knowledge is blocked?

- Knowledge is present, but in some situations, it is not available to the relevant stakeholders.

- Knowledge is present, but not yet translated into decision support tools.

- How can research results be converted into policy messages.

- Insufficient contact with farmers organizations.

- Which socio-economic aspects should be considered?

- Economic incentives (either policy driven, or market driven) may be misguiding and/or contraproductive.

- Social and cultural perception.

- Conflicting interests of different stakeholders.

- Which paradigm shifts are needed?

- Is a whole paradigm shift required from land and soil managers, i.e. to go from protection to sustainable use. 


\section{$9 \quad$ Outcomes Workshop}

South Africa has a dynamic and active group of farmers, agricultural researchers and extension workers testing and promoting the use of CA principles with farmers being at the centre of the innovation. In the Netherlands, circular agriculture has become a key focus of agricultural development. As agricultural research in both South Africa and the Netherlands is highly developed, there are ample possibilities for joined research projects. Based on a constructive workshop and field visit December 3-5, 2019 on "The role of soil C in Conservation Agriculture and carbon sequestration in South Africa" the following outline for research on CA has been developed. After a lively workshop in Bloemfontein organised by the university of the Free State (Linus Franke and Nester Mashingaidze) and Wageningen Environmental Research (Saskia Keesstra and Henk Wösten).

In Annex 3, 4 and 5 photos of the flipovers are shown where the answers the questions we asked the participant to reflect on are given.

In general we can give the following answers for workshop 1:

The 5 questions were asked, but they were answered in an integrated way.

1. What is your definition of Conservation Agriculture?

2. Does the description of CA of FAO match current practices listed as CA in ZA?

3. What are the requirements?

4. What are the benefits?

5. What are the draw backs?

The message back was that in South Africa CA may be seen as an intermediate step towards Regenerative Agriculture and the FAO's definition does not include the integration of livestock in the farm system, which by the workshop participants is seen as an essential part of the successful implementation.

The key requirements were identified as:

- Knowledge

- Equipment

- Change in mindset

- Time for soil build-up

- Area specific plan development (no one recipe for success)

The benefits identified were:

- Yield stability

- Soil quality and all benefits related to that

- More yield with less resources (resource use efficiency)

- Free natural services

The draw backs identified were:

- It is a totally different system, which means a learning curve including making mistakes

- Adapting to the new system is knowledge intensive

- The revenues take time; benefits are long-term

- On acidic soils liming is needed and the mobility of lime in the soil is limited

- Rules for implementation should not be too strict

Workshop 2:

1. What would you like to have accomplished in terms of sustainable agricultural land use in 20 years?

2. What role do you see for CA in this view

3. How would this lead to better carbon sequestration in soils

4. Which effect would this have on agricultural yield? 
Future vision:

The group in the workshop had the vision for SA that:

- No more environmental damage because of farming

- A positive $C$ footprint

- Livestock integration for profitability efficiency

- Sustainable or even regenerative

- Increased production with low inputs, cheaper food, higher yields

- Plant breeding adapted to CA

- Lower degradation

- Increased water availability

- Better nutrient cycling/fertility

- Adoption of different approaches to increase production: biochar/cover crops/CA

- Turn abandoned land back into production via CA

- One vision/one language: standardize terminology

- Communal areas: apply RA: rangeland should be managed better

- Research in rangeland conservation; apply regenerative agriculture

- $100 \%$ pass rate

- All production systems should move towards a closed system/regenerative system

- Change mindset towards RA

- Awareness under farming community

Workshop 3:

What is needed?

- Mind shifts: we need

- Awareness

- Education and training

- Policy change

- System approaches

- Economical data and incentives

- Efficient, cheap, nutritious food through CA

- Certification

- Guidelines for switching to CA

- Paradigm shift

- Farmer support groups

- Multi-disciplinary

- Peer pressure and pressure from lobbies

Why do some farmers not like CA:

- Perceived as risky

- Cognitive Dissonance: believes/traditions/Ideas/Ignorance

- "their system still works" so why change?

- Addiction to KW's and chemicals

- Lazy/lack of patience: prefer a quick fix

- Lack of appropriate support systems (education + extension)

- No appropriate incentives

- Barriers:

- Commitment from government

- Government stimulates conventional practices

- Not enough extension officers

- Need for positive examples

- Instability around land reform

- Logistics for smallholder farmers

- Sustainability is long-term

- Context-specific knowledge

- Very small farms owned by smallholders 


\section{Roadmap for research in South Africa regarding sustainable soil management for Climate Change Mitigation}

Soils represent an enormous reservoir of carbon, containing nearly twice as much carbon as the atmosphere. Agricultural soils, particularly those degraded in organic carbon, have a large potential for carbon storage. Soil organic carbon is vital in controlling soil quality, agricultural productivity, biodiversity, and water protection. Storing atmospheric carbon in agricultural soils may also be an important component of climate mitigation efforts.

To identify the research needs in South Africa the workshops have been designed to deliver a roadmap for research in South Africa on sustainable agricultural soil management. In the workshops the following topics for potential collaborative research were identified:

1. Given that farmers drive the transformation to CA practices in South Africa, how can monitoring framework be developed for implementing CA both on large- and small-scale farms to assess how CA is adopted and how the adoption of CA practices affect the sustainability of production.

2. Which kind of indicators do we need on farm scale statistics to quantify the effect of CA measures.

3. Investigate what the best cover crops are in terms:
a. protecting the soil from erosion,
b. enhance water infiltration,
c. nutritional value for cattle.

4. Integration of livestock in CA to increase the resilience of the CA system.

a. What are the benefits of cattle in making CA more circular in terms of nutrient cycling, pest control, soil health and economic return?

b. What is the potential of mixed farming systems in the Netherlands?

c. What is the $\mathrm{C}$ footprint of integrated crop-livestock systems, in comparison with nonintegrated systems?

5. Impact of existing/non-existing subsidy system on the implementation of sustainable farming systems.

6. Socio-economic drivers and barriers in South Africa and the Netherlands for the transition to(wards) sustainable farming.

7. How can we raise more awareness on the benefits of sustainable farming among land managers in general and farmers in particular both in NL as SA?

8. How can we incorporate key stakeholders in the whole food system in the development of a more sustainable food production system?

\section{Research methodology}

CA research requires a methodology of active involvement of farmers as they drive the CA innovations and are the main implementers. Consequently, a co-learning environment involving researchers, farmers, extension workers, and private sector is required. Existing farmer study groups as well as creation of narratives are ways to create an environment of collaboration among different stakeholders. This type of action research differs from the traditional methodology of curiosity driven research and therefore needs attention in order to be effective.

\section{Research funding}

The Netherlands government supports further collaboration between the Netherlands and South Africa. As such, they funded this first initiative. However, for further work other donors need to be approached as well. Possibilities are linking South Africa with an ongoing EU initiative, PhD fellowships, NWO - NRF joined calls, and attracting interest from the private sector. 
Currently we are looking into a possible funding through a so-called Public Private partnership (PPS) funded by the Dutch Government in collaboration with the top sector funding in the Netherlands. At the ministry of Agriculture in The Netherlands there is the ambition to make our agricultural sector more international, and a PPS in collaboration with South Africa would fit well into this scope.

Currently, there are some exploratory talks between the Dutch 'Soil Heroes' and WUR. We would like to link to South African Partners such as Grain SA to see how we could join forces. 


\section{References}

Akker, J.J.H. van den, F. de Vries, G.D. Vermeulen, M.J.D. Hack-ten Broeke en T. Schouten. 2012. Risico op ondergrondverdichting in het landelijk gebied in kaart. (in Dutch) Wageningen, Alterra, Alterra-Report 2409.

Amundson, R. and Biardeaub, L. 2018. Soil carbon sequestration is an elusive climate mitigation tool. 11652-11656 | PNAS | November 13, 2018 | vol. 115 | no. 46. Available online: www.pnas.org/cgi/doi/10.1073/pnas.1815901115 Accessed 7/11/2019

Cheesman, S., Thierfelder, C., Eash, N.S., Kassie, G.T. and Frossar, E. 2016. Soil carbon stocks in conservation agriculture systems of Southern Africa. Soil Tillage and Research 166, 99-109.

Corbeels, M., Cardinael, R., Naudin, K., Guibert, H., Torquebiau, E. 2019. The 4 per 1000 goal and soil carbon storage under agroforestry and conservation agriculture systems in sub-Saharan Africa. https://doi.org/10.1016/j.still.2018.02.015

Crowther, T. W., Todd-Brown, K. E., Rowe, C. W., Wieder, W. R., Carey, J. C., Machmuller, M. B., ... \& Blair, J. M. (2016). Quantifying global soil carbon losses in response to warming. Nature, 540(7631), 104.

Du Preez, C.C., Van Huysteen, C.W. and Mnkeni, P.N.S. 2011. Land use and soil organic matter in South Africa 1: a review on spatial variability and the influence on rangeland stock production. S Afr J Sci. 2011; 107(5/6)., Art. \#354, 8 pages. Doi:10.4102/2ajs.v107i5/6.354.

EEA, C. 2012. CORINE land cover.

Faber et al. 2011. Droogteresistentie van grasland in de Gelderse Vallei. Kijk eens wat vaker onder de graszode. Wageningen, Alterra-Rapport 2373.

Eurofins. 2017. Kwaliteit organische stof inzichtelijk gemaakt.http://eurofins-agro.com/nl$\mathrm{nl} /$ kwaliteit_organische_stof_inzichtelijk

Faber, F., H. Wösten, G. Bakker, J. Bokhorst, E. Hummelink, I. Laros, of fear Brink. Deru. and of Eekeren. 2011. of grasslands in the. on https what see at others the sods of grass. Wageningen, Alterra-Rapport_Alterra_LBI 22 augustus. ISSN 1566-7197. 116 p.

FAO (2019) (http://www.fao.org/conservation-agriculture/en/

Findlater, K. 2015. Improving South African grain farming. PhD thesis, University of British Columbia, Vancouver, Canada.

Gariano, S. L., \& Guzzetti, F. 2016. Landslides in a changing climate. Earth-Science Reviews, 162, 227-252.

Gonzalez-Sanchez, E.J., Veroz-Gonzalez, O., Conwayd, G., Moreno-Garciae, M., Amir Kassam, A., Mkomwa, S., Ordoñez-Fernandez, R., Triviño-Tarradasa,P. and Carbonell-Bojollo, R. 2019. Metaanalysis on carbon sequestration through Conservation Agriculture in Africa. Soil and Tillage Research 190, 22-30. https://doi.org/10.1016/j.still.2019.02.020

Hijbeek et al. 2017. Do organic inputs matter - a meta-analysis of additional yield effects for arable crops in Europe. Plant Soil 411:293-303.

Jurgilevich, A., Birge, T., Kentala-Lehtonen, J., Korhonen-Kurki, K., Pietikäinen, J., Saikku, L. and Schösler, H., 2016. Transition towards circular economy in the food system. Sustainability 8(1): 69.

Kassam, A., Friedrich., T. and Derpsch, R. 2018. Global spread of Conservation Agriculture, International Journal of Environmental Studies. https://doi.org/10.1080/00207233.2018.1494927

Keesstra, S. D., Bouma, J., Wallinga, J., Tittonell, P., Smith, P., Cerdà, A., ... \& Bardgett, R. D. 2016. The significance of soils and soil science towards realization of the United Nations Sustainable Development Goals. Soil.

Klimaatberaad. 2018. Ontwerp van het Klimaatakkoord. E. Nijpels (Ed.), (pp. 222). the Hague: Social Economic Board.

Kortleven, J., 1963. Kwantitatieve aspecten van humusopbouw en humusafbraak. Verslagen Landbouwkundig Onderzoek 69.1.

Kreuzwieser, J., \& Gessler, A. 2010. Global climate change and tree nutrition: influence of water availability. Tree Physiology, 30(9), 1221-1234. 
Laborde, J. P., Wortmann, C. S., Blanco-Canqui, H., Baigorria, G. A., Lindquist, J. L., 2020. Identifying the drivers and predicting the outcome of conservation agriculture globally. Agricultural Systems, $177,102692$.

Lal, R. 2016. Soil health and carbon management. Food Energy Secur. 5:212-222

Hobbs, P.R., Sayre, K., Gupta, R. 2008. The role of conservation agriculture in sustainable agriculture. Philos. Trans. R. Soc. B Biol. Sci. 363, 543-555. https://doi.org/10.1098/rstb.2007.2169

Mashingaidze, N., Twomlow, S., Madakadze, I.C., Mupangwa, W. \& Mavunganidze, Z. 2017. Weed growth and crop yield responses to tillage and mulching under different crop rotation sequences in semiarid conditions. Soil Use and Management. 33, 311-317. https://doi.org/10.1111/sum.12338

Mtyobile, M., Muzangwa, L., Nyari, P. and Mnkeni, S. 2019. Tillage and crop rotation effects on soil carbon and selected soil physical properties in a Haplic Cambisol in Eastern Cape, South Africa. Soil \& Water Res. https://doi.org/10.17221/176/2018-SWR

Ngwira, A., Sleutel, S. and De Neve, S. 2012. Soil carbon dynamics as influenced by tillage and crop residue management in loamy sand and sandy loam soils under smallholder farmers' conditions in Malawi. Nutr Cycl Agroecosyst. DOI 10.1007/s10705-012-9492-2

Rahmati et al. 2018. Development and analysis of the Soil Water Infiltration Global database. Earth Syst. Sci. Data, 10:1237-1263.

Roe, S., Streck, C., Obersteiner, M., Frank, S., Griscom, B., Drouet, L., Fricko, O., Gusti, M., Harris, N., Hasegawa, T., Stehfest, E., Lawrence, D., 2019. Contribution of the land sector to a $1.5{ }^{\circ} \mathrm{C}$ world. Nat. Clim. Chang. 9, 817-828. https://doi.org/10.1038/s41558-019-0591-9

Reubens, B., D., D., Ruysschaert G. 2010. Bodemkwaliteit en landbouw: a literature review. Activiteit 1 van het Interregproject BodemBreed. Instituut voor Landbouw- en Visserijonderzoek (ILVO), Merelbeke-Lemberge, België. 203 p.

Schouten. 2018. Agriculture, nature and food: valuable and connected - the Netherlands as frontrunner in a circularly agriculture. (in Dutch pp. 37). Den Haag: Ministerie van Landbouw, Natuur en Voedselkwaliteit.

Schipper et al. 2015. Goede grond voor een duurzaam watersysteem Verdere verkenningen in de relatie tussen agrarisch bodembeheer, bodemkwaliteit en waterhuishouding. Amersfoort, STOWARapport 2015-19.

Schütte, S., Schulze, R. and Paterson, G. 2019. Identification and mapping of soils rich in organic carbon in South Africa as a climate change mitigation option. Department of Environmental Affairs, Pretoria, South Africa.

SmartSoil project. 2015. Sustainable farm management aimed at reducing threats to soils under climate change. European Union's Seventh Framework Programme, grant agreement no. 289694.

Smit, A., Van Beek, C. L., \& Hoogland, T. 2007. Risicogebieden voor organische stof - Ontwerp van een methodologie voor het aanwijzen van 'risk areas' t.b.v. de EU Kaderrichtlijn bodem (pp. 51). Wageningen: Wageningen UR.

Smith, P. 2004. Soils as carbon sinks: The global context. Soil Use Manag. 20, 212-218. https://doi.org/10.1079/SUM2004233

Smith, P., Martino, D., Cai, Z., Gwary, D., Janzen, H., Kumar, P., ... \& Scholes, B. 2007. Greenhouse gas mitigation in agriculture. Philosophical transactions of the royal Society B: Biological Sciences, 363(1492), 789-813.

Smith, P. 2016. Soil carbon sequestration and biochar as negative emission technologies. Glob Change Biol. 22:1315-132

Smith, P., Adams, J., Beerling, D.J., Beringer, T., Calvin, K.V., Fuss, S., Griscom, B., Hagemann, N., Kammann, C., Kraxner, F., Vicente, J.L., Keesstra, S. 2019. Land-Management Options for Greenhouse Gas Removal and Their Impacts on Ecosystem Services and the Sustainable Development Goals, Annual Review of Environment and Resources. https://doi.org/10.1146/annurev-environ-101718-033129

Swanepoel, C.M., Rötter, R.P., van der Laan, M., Annandale, J.G., Beukes, D.J., Du Preez, C.C., Swanepoel, L.H., van der Merwe, A., Hoffmann, M.P.2018.The benefits of conservation agriculture on soil organic carbon and yield in southern Africa are site-specific. Soil tillage Research 183 , 72-82 https://doi.org/10.1016/j.still.2018.05.016

TCB. 2016. Advies Toestand en dynamiek van organische stof in Nederlandse landbouwbodems. Technische Commissie Bodem (J. v. Wensem (Ed.), rapport TCB A110, pp. 25. The Hague. UNCCD. 1994. Article 2 of the Text of the United Nations Convention to Combat Desertification. 
UNFCCC. 2015. Join the 4/1000 Initiative. Soils for Food Security and Climate. Lima- Paris Action Agenda.

USDA Natural Resources Conservation Service. 2006. Soil Organic Carbon map. Available online: https://www.nrcs.usda.gov/wps/portal/nrcs/detail/soils/use/?cid=nrcs142p2_054018 Accessed $6 / 11 / 2019$

Williams et al. 2017. Organic Farming and Soil Physical Properties: An Assessment after 40 Years. Agron. J. 109:600-609.

UNFCCC, V. 2015. Adoption of the Paris agreement. United Nations Office at Geneva, Geneva.

Wösten et al. 2001. Waterretentie- en doorlatendheidskarakteristieken van boven- en ondergronden in Nederland: de Staringreeks. Vernieuwde uitgave 2001. Wageningen, Alterra-Rapport 153.

Williams et al., 2017. Organic Farming and Soil Physical Properties: An Assessment after 40 Years. Agron. J. 109: 600-609.

Wösten, J.H.M., G.J. Veerman, W.J.M. de Groot en J. Stolte. 2001. Waterretentie- en doorlatendheidskarakteristieken van boven- en ondergronden in Nederland: the Staringreeks. Renewed edition 2001 Alterra, Research Instituut voor de Groene Ruimte, Wageningen, Alterrarapport $153.86 \mathrm{p}$. 


\section{Annex 1 Program workshop}

3rd December 2019:

12:30 Registration, light lunch available

13:00 Opening by Jack Vera

13:20 Introduction workshop (Linus Franke and Saskia Keesstra)

13:40 What is Conservation Agriculture? (Linus Franke)

14:00 Effect of Conservation Agriculture on carbon sequestration and policies related to that (Saskia Keesstra)

14.30 Coffee / Tea break

15:00 Effect of Conservation Agriculture on soil fertility, water availability and crop production (Henk Wösten)

15:30 1st workshop on perception and knowledge of Conservation Agriculture in South Africa

16:30 Plenary reporting back of 1st workshop

$19.00 \quad$ Dinner

\section{4th December 2019}

8:00 Participants presenting their Conservation Agricultural activities / research through brief (10-20 mins) presentations

$10.00 \quad$ 2nd workshop: Aspirational targets (coffee during workshop)

$11.00 \quad$ Report back on 2nd workshop

12.00 International policy on carbon sequestration (Saskia Keesstra)

12:45 Lunch

13:30 3rd workshop on barriers for upscaling Conservation Agriculture in South Africa

14:30 Report back on 3rd workshop

15:00 Coffee / tea break

15:30 Plenary discussion on how to move (research on?) Conservation Agriculture forward in South Africa (or not)

16:30 Closing

\section{5th of December 2019:}

Optional excursion to Conservation Agriculture trials in the Eastern Free State. 


\section{Annex 2 List of participants of the workshop}

\section{Organizers}

Linus Franke (University of the Free State)

Henk Wösten (Wageningen University and Research)

Saskia Keesstra (Wageningen University and Research)

\section{Participants}

Pieter Swanepoel (Stellenbosch University)

Tesfay Aray (University of Forth Hare)

Solomon Beyene (University of Fort Hare)

Jack Vera (NL embassy Pretoria)

Johann Strauss (Department of Agriculture Government of the Western Cape)

Lientjie Visser (ARC Betlehem)

Michael Kidson (ARC Pretoria)

Hendrik Smith (Grain SA)

Danie Slabbert (Farmer)

Gerry Rumen (Farmer)

Phesheya Dlamini (University of Limpopo)

Nester Mashingaidze (University of the Free State)

Neo Mathinya (University of the Free State)

Elmarie Kotze (University of the Free State)

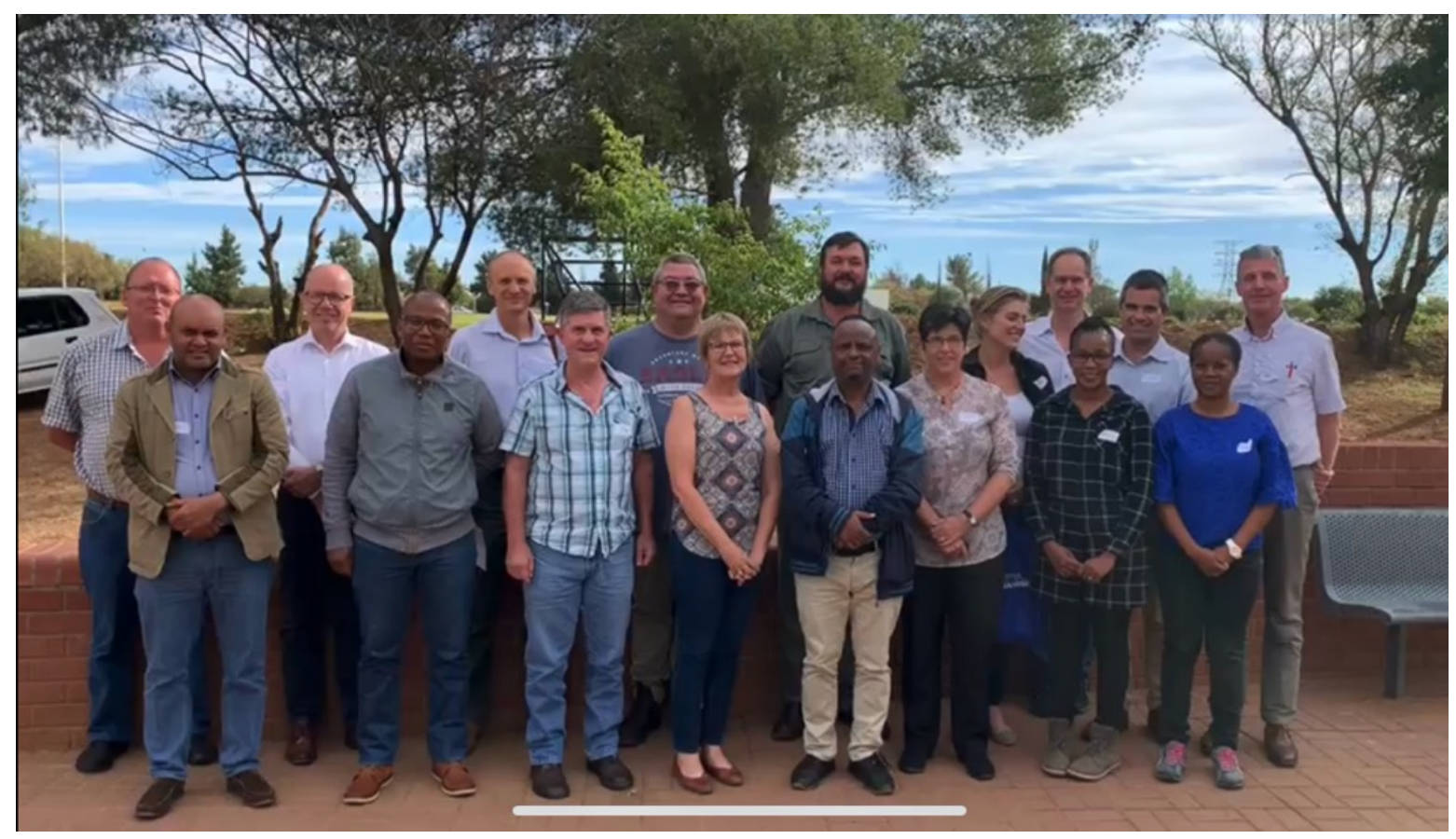




\section{Annex 3 Workshop 1 set up: Perception}

Perception and knowledge of Conservation Agriculture in South Africa.

1 hour

15 min plenary reporting back

Questions:

1. What is your definition of Conservation Agriculture?

2. Does the description of CA of FAO match current practices listed as CA in ZA?

3. What are the requirements?

4. What are the benefits?

5. What are the draw backs?

\section{Workshop outcomes on flipovers}

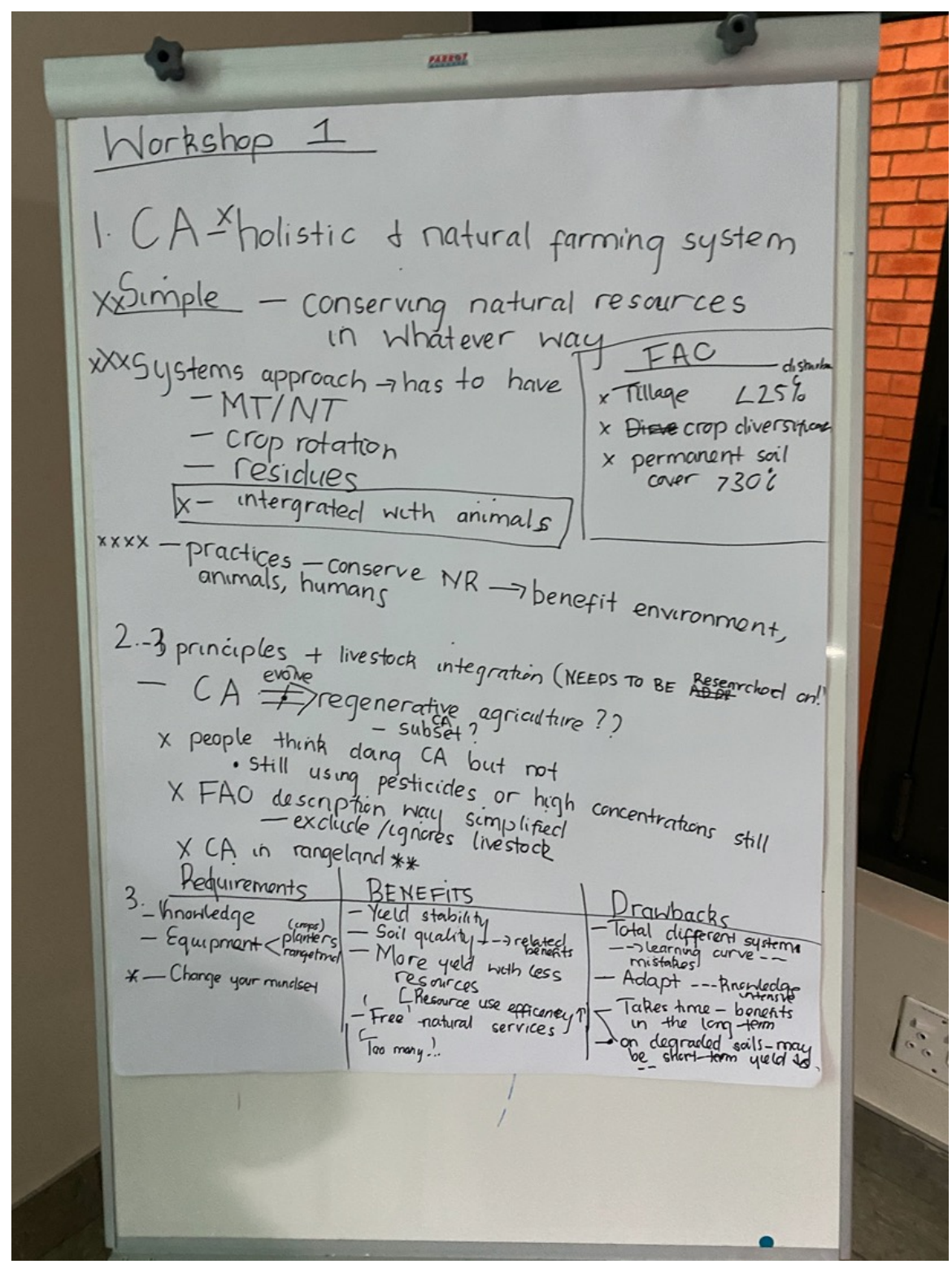


Workshop on CA

DA7 1: 03 Dec 2019

Animal integration \& cover crops $\rightarrow$ Mates for a mure profitable CoProvides texibility for the system

* Think of integration levels * within time a space

Regenerative practices

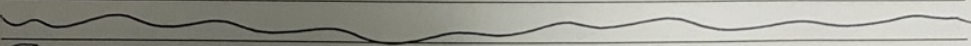

Group Answers: Workshop no: 1 Perception

1: Definition of $C A$

Lo 3 principles with the addition of 2 , if the system allows: No till, diversity, cover crop, livestoct, crop rotation

Key: Area specific management

* Nain question - Degree of adopton of these principles

Fertilizers, herbiades $\rightarrow$ What are the trade offs

$$
\rightarrow \text { Sall bulogy remains the black box }
$$

2: Fine as is with a few additions

\&enefits

3: Requirements: Mind shipt, technology, time for soil build-up the knowledge base, no recipies as is area ipecific

4:Orawbacks: knowledge requirement, soil acidity-lime is immobile don't be too rigid with the management

Do why is cirlical for the implimentation of the how

$$
\begin{array}{r|l}
\text { Accommodation \& } \\
\text { Catering Services }
\end{array}
$$




\section{Annex 4 Workshop 2 set up: Aspirational targets}

Aspirational targets

1 hour

15 min plenary reporting back

Questions:

1. What would you like to have accomplished in terms of sustainable agricultural land use in 20 years?

2. What role do you see for CA in this view

3. How would this lead to better carbon sequestration in soils

4. Which effect would this have on agricultural yield?

\section{Workshop outcomes on flipovers}

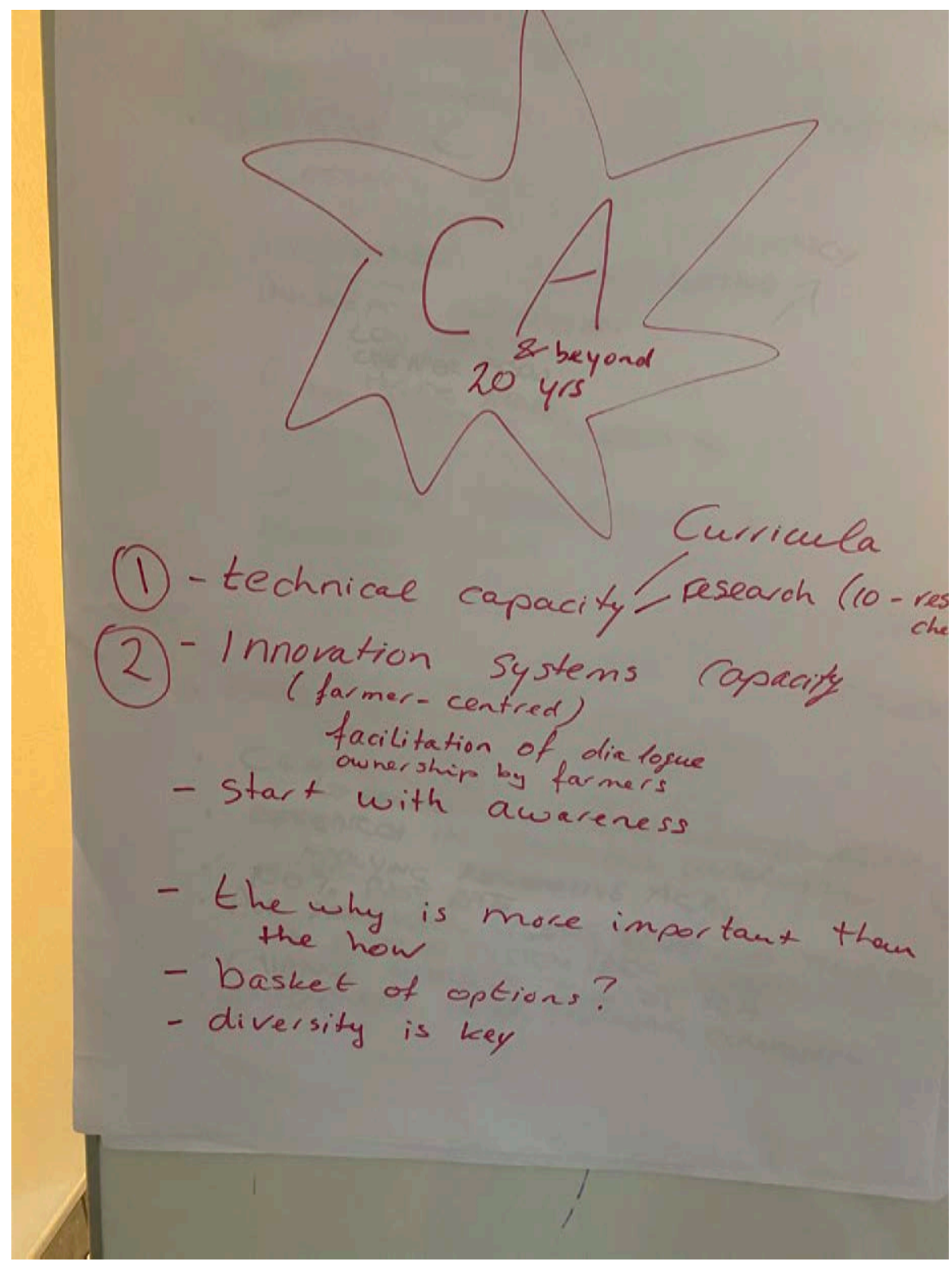




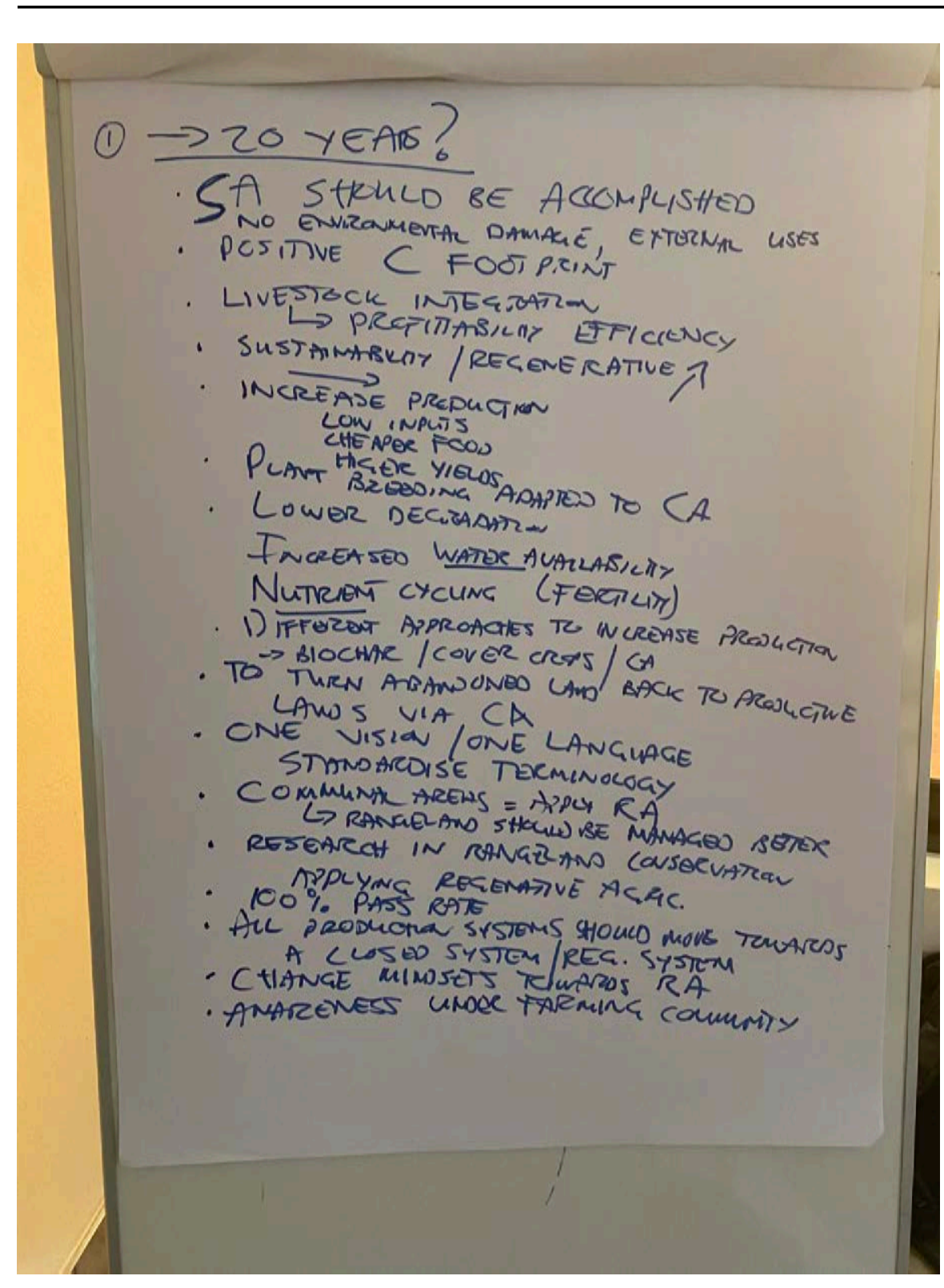


Annex 5 Workshop 3 set up: barriers and solutions

Barriers and solutions for upscaling Conservation Agriculture in South Africa 1 hour

15 min plenary reporting back

Questions:

1. What do you think is needed to implement CA in SA?

2. Why do some farmers not like CA?

3. Which other barriers exist for the upscaling of CA in SA?

4. Which incentives would be necessary to change this situation?

Workshop outcomes on flipovers

2. Why do some farmers NoT Like (G)?

- Risk (Perceive dr)

- Cognitive Disononce Tribes) L -Believes

- Ignorance J- Traditions

- Ignorance j- Ideas

- "Their system still works"

- Addiction to kW' and chemicals!

- Lazy /lack of patience (want quick fix)

- Not good support systems

- (education, research + extension) appropriate

46 | Wageningen Environmental Research report 3024 
Group 2

- Barriers

Commitment from government Government stimulation conc. Praetries, Extension officer Curricula

Need for positive examples Instability around land reform Logistics for small holders Sustainability is fory-term. Lore Contert-specific knowledge Guidelines for switching to $O A$ Farmer support groups

Paradigm shift Multi-disciplinarity Pressure from Lobbies Peer pressure

Wageningen Environmental Research report $3024 \quad 47$ 


\section{Annex 6 Two-pager deliverable published in Agro-berichten}

The future of Conservation Agriculture: integrating livestock into farming systems paves the
way towards our dot on the horizon: regenerative agriculture

South Africa has a dynamic and active group of farmers, agricultural researchers and extension workers testing and promoting the use of CA principles with farmers being at the centre of the innovation. In the Netherlands, circular agriculture has become a key focus of agricultural development. As agricultural research in both South Africa and the Netherlands is highly developed, there are ample possibilities for joined research projects. Based on a constructive workshop and field visit from December 3-5, 2019 on "The role of soil C in Conservation Agriculture and carbon sequestration in South Africa" the following outline for research on CA has been developed. After a lively workshop in Bloemfontein organised by the university of the Free State (Linus Franke and Nester Mashingaidze) and Wageningen Environmental Research (Saskia Keesstra and Henk Wösten).

Conservation Agriculture (CA) is a farming system that promotes minimum soil disturbance (i.e. no tillage), maintenance of a permanent soil cover, and diversification of plant species. It enhances biodiversity and natural biological processes above and below the ground surface, which contributes to increased water and nutrient use efficiency and to improved and sustained crop production. The following three principles apply. 1) Minimum mechanical soil disturbance (i.e. no tillage) through direct seed and/or fertilizer placement. 2) Permanent soil organic cover (at least 30 percent) with crop residues and/or cover crops. And 3) Species diversification through varied crop sequences and associations involving at least three different crops. During the workshop in Bloemfontein, South Africa, from 3-5 December 2019, a fourth principle was identified as being crucial for successful CA implementation, namely: 4) Animal husbandry which involves including animals (cattle, sheep, chicken) in the system.
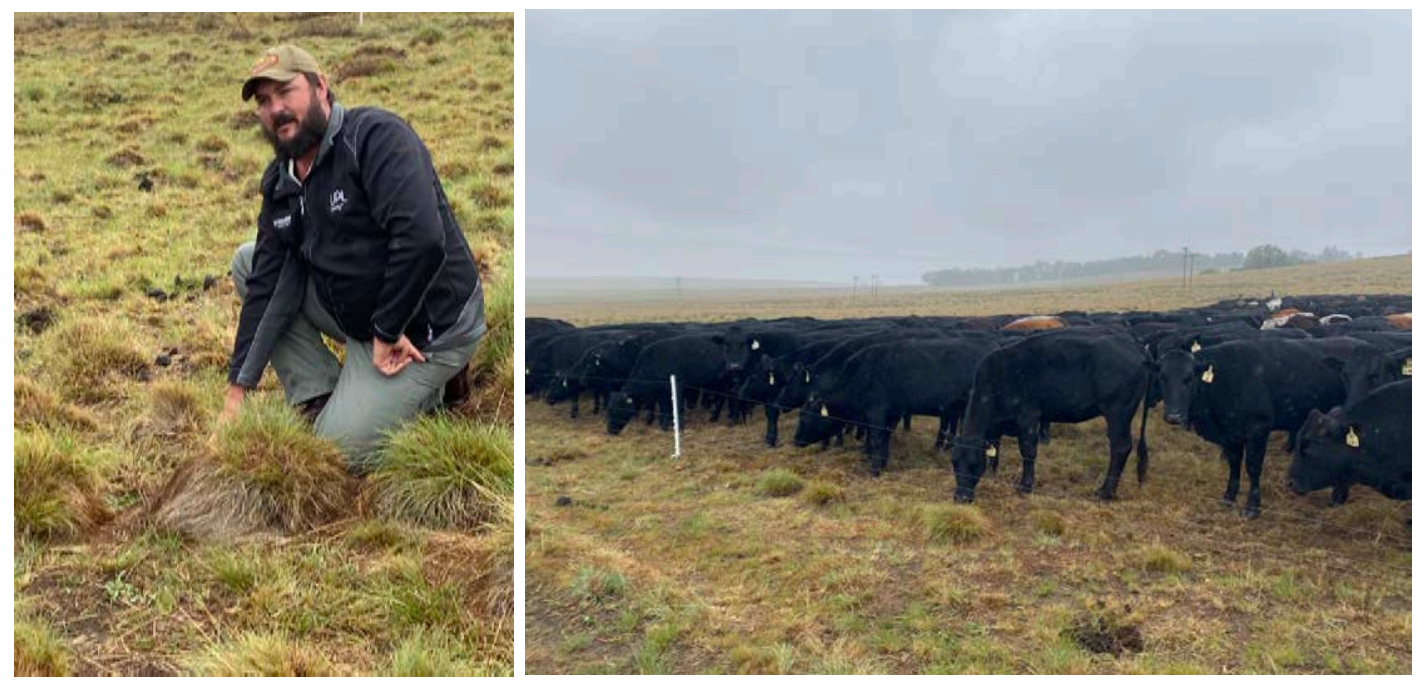

Visionary farmer Danie Slabbert (near the village of Reitz) and his ultra-high density grazing system improving soil health, biodiversity, grass quality (veld quality) and income. 


\section{Lessons learned in South Africa: \\ Integrating livestock into crop systems}

In the past also in the Netherlands most farms had a mixed farming system, using the manure of the livestock to fertilize the arable fields. Nowadays due to specialization, optimization and heavy regulations most farms have only arable fields, orchards or livestock. Focusing on circular agriculture it is interesting to look at the way South African farmers are bringing back livestock into their annual cropping system.

In the workshop in South Africa we initially focused on the role conservation agriculture may play in climate mitigation and how these types of measures could be upscaled to large-scale as well as to small-holder farms.

In our workshop there was a strong voice to take conservation agriculture to the next level of regenerative agriculture, as the ultimate goal. However, this goal has to be reached in manageable steps.

The main insights from the workshop were:

\section{Economic and environmental sustainability is possible without subsidy}

In South Africa there is no subsidy system as it exits in Europe. Therefore, any change in the management system made by a farmer must be economically viable. In the opinion of several farmers and representatives of farmers organizations present in the workshop, the best way to reach this goal is to integrate livestock in farming systems. The grazing animals reduce fertilizer input and bring income by selling the meat. Their trampling incorporates into the soil the manure and crop residues they do not eat. This increases soil carbon, soil health and biodiversity, in the soil as well as above.

\section{The transition towards sustainable farming can also be slow: Every step into the direction of sustainability if a good one}

The step from conventional farming to regenerative agriculture is a too big a step for most farmers. Therefore intermediate steps need to be promoted too. Because South Africa does not have a subsidy system like in Europe, changing towards healthier food production from an environmental and human health point of view depends on the willingness and vision of each farmer. In our workshop dr. Hendrik Smith from Grain SA explained us the 7 steps towards regenerative agriculture:

\begin{tabular}{|c|c|c|c|c|c|c|c|}
\hline Stage & 1 & 2 & 3 & 4 & 5 & 6 & 7 \\
\hline 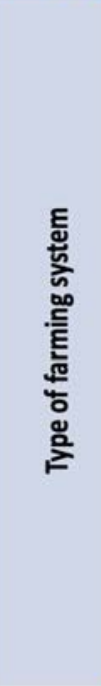 & $\begin{array}{l}\text { Conv. } \\
\text { tillage }\end{array}$ & $\begin{array}{l}\text { Min. or } \\
\text { reduced } \\
\text { tillage }\end{array}$ & \begin{tabular}{l}
\multicolumn{1}{c}{$\begin{array}{c}\text { Conv. no } \\
\text { tillage (NT) }\end{array}$} \\
(Direct \\
seeding \\
equipment \\
using tines). \\
Production \\
system lacks \\
adequate soil \\
cover and \\
sound crop \\
rotations. \\
High use of \\
external \\
inputs
\end{tabular} & $\begin{array}{l}\begin{array}{l}\text { Conv. zero } \\
\text { tillage (ZT) }\end{array} \\
\text { (Direct } \\
\text { seeding } \\
\text { equipment } \\
\text { using discs). } \\
\text { Production } \\
\text { system lacks } \\
\text { adequate soil } \\
\text { cover and } \\
\text { sound crop } \\
\text { rotations. } \\
\text { High use of } \\
\text { external } \\
\text { inputs }\end{array}$ & $\begin{array}{l}\qquad \text { CA }_{\text {HEI }} \\
\text { (NT or ZT } \\
\text { using high } \\
\text { quantities of } \\
\text { external } \\
\text { artificial inputs } \\
\text { (i.e. fertilizer, } \\
\text { herbicides, } \\
\text { pesticides). } \\
\text { Production } \\
\text { system has } \\
\text { adequate soil } \\
\text { cover and } \\
\text { sound crop } \\
\text { rotations. }\end{array}$ & $\begin{array}{l}\text { (NT or ZT } \\
\text { using low } \\
\text { quantities of } \\
\text { external } \\
\text { artificial } \\
\text { inputs (i.e. } \\
\text { fertilizer, } \\
\text { herbicides, } \\
\text { pesticides). } \\
\text { Production } \\
\text { system has } \\
\text { adequate soil } \\
\text { cover and } \\
\text { sound crop } \\
\text { rotations. }\end{array}$ & $\begin{array}{l}\text { (ZT using } \\
\text { very little or } \\
\text { no external } \\
\text { artificial } \\
\text { inputs (i.e. } \\
\text { fertilizer, } \\
\text { herbicides, } \\
\text { pesticides). } \\
\text { Production } \\
\text { system has } \\
\text { adequate } \\
\text { soil cover } \\
\text { and sound } \\
\text { crop } \\
\text { rotations. }\end{array}$ \\
\hline
\end{tabular}




\section{Vision and love for the land: a good farmer is a steward of the land}

Most famers love their land, but may be caught in a socio-economic trap by doing as their fathers or as their neighbors. Alternative strategies that are holistic, local and custom made are needed to move into the right direction while being in reach of the farmers context. Narratives are needed to gain trust and to show that regenerative agriculture is a reachable a dot on the horizon for all. Hands-on tools and knowledge should be provided enabling farmers to earn a good living from their land in a sustainable way while being respected in their community.

\section{Ways to find hands-on local, but holistic solutions for every farm}

Typically these solutions will be developed in collaboration with farmers making it possible to serve public goals such as climate change mitigation through carbon sequestration in soils and biodiversity restoration; while ensuring a good livelihood for the farmer. 


\section{Annex 7 Landbou berichten}

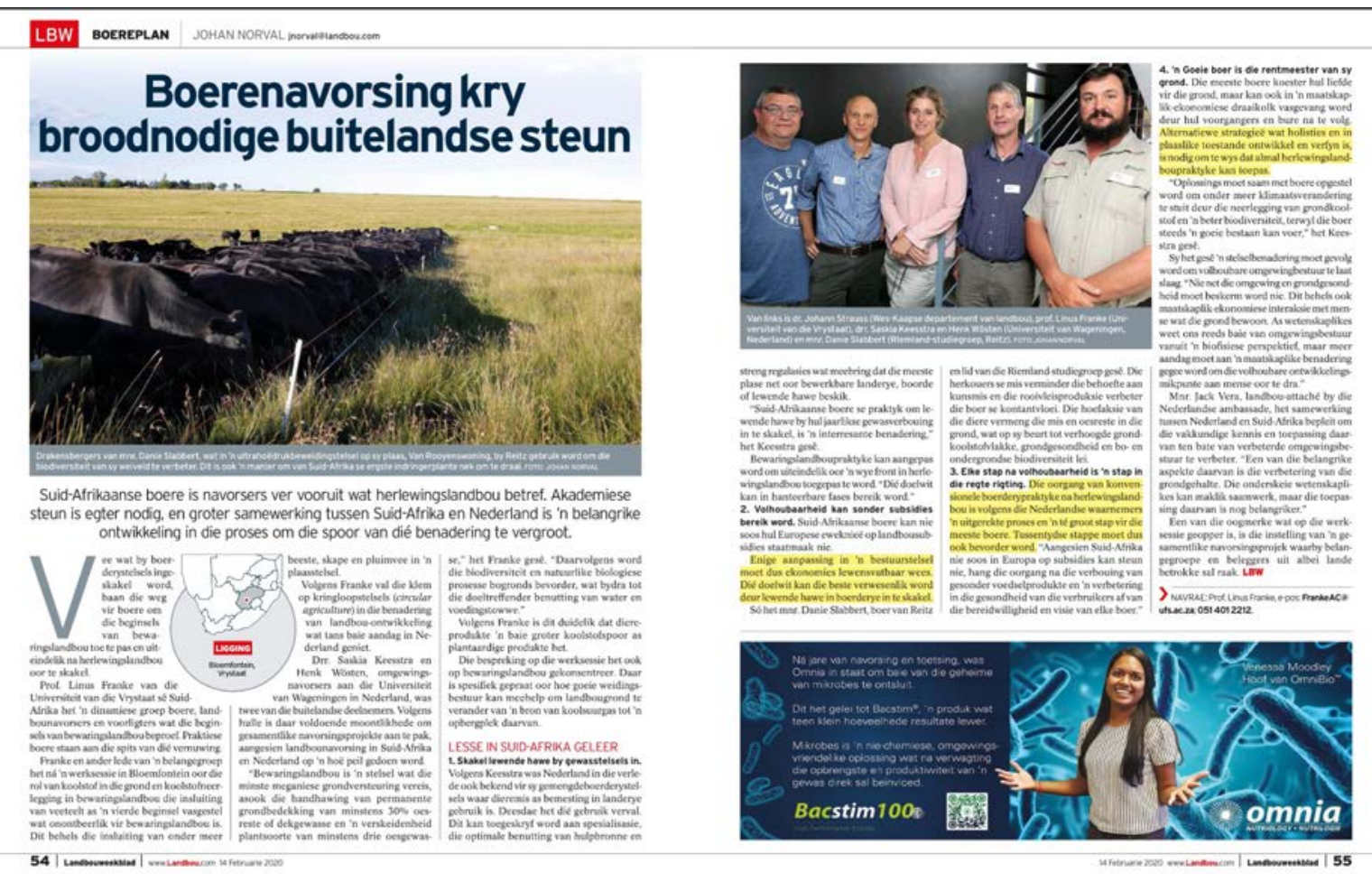


Wageningen Environmental Research P.O. Box 47

6700 AA Wageningen

The Netherlands

T +31 (0)317480700

www.wur.nl/environmental-research

Wageningen Environmental Research

Report 3024

ISSN 1566-7197
The mission of Wageningen University \& Research is "To explore the potential of nature to improve the quality of life". Under the banner Wageningen University \& Research, Wageningen University and the specialised research institutes of the Wageningen Research Foundation have joined forces in contributing to finding solutions to important questions in the domain of healthy food and living environment. With its roughly 30 branches, 5,000 employees and 12,000 students, Wageningen University \& Research is one of the leading organisations in its domain. The unique Wageningen approach lies in its integrated approach to issues and the collaboration between different disciplines.

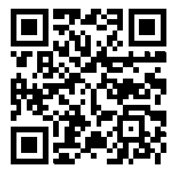





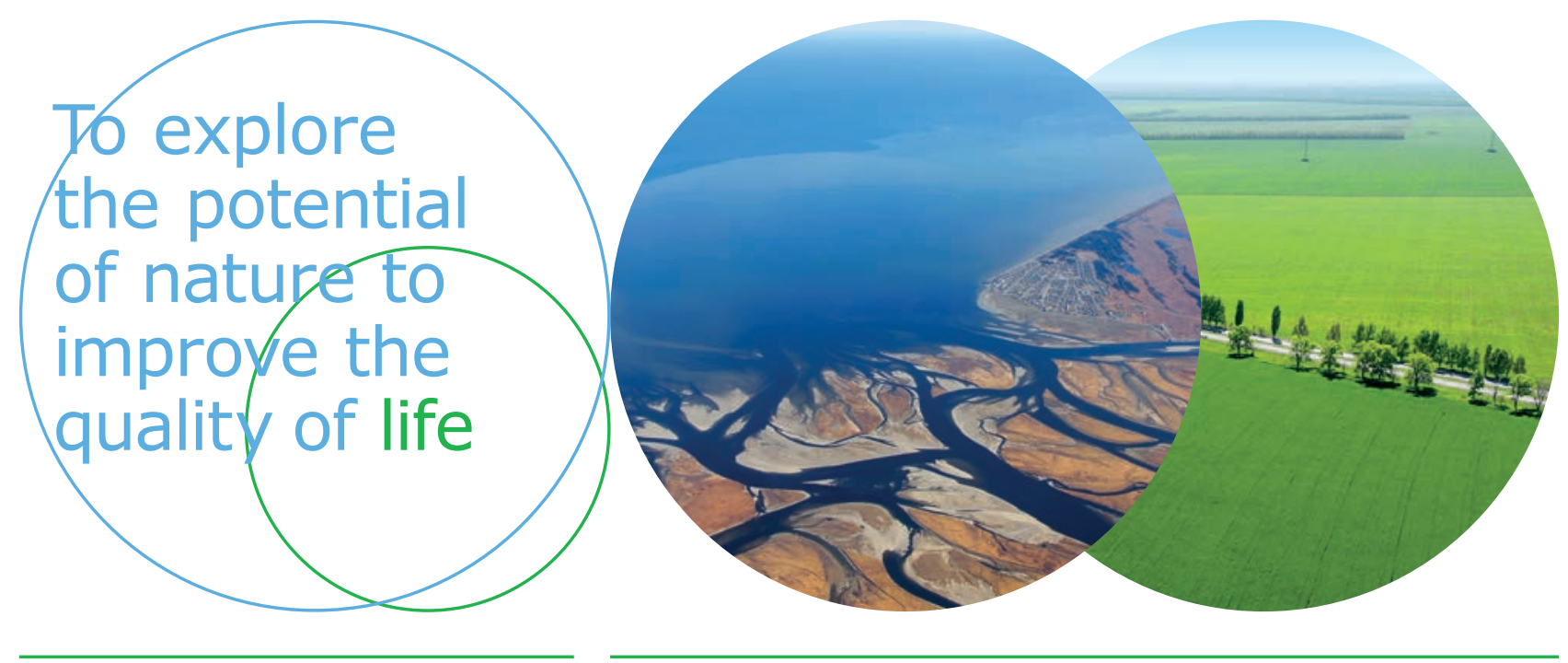

Wageningen Environmental Research P.O. Box 47

$6700 \mathrm{AB}$ Wageningen

The Netherlands

$\mathrm{T}+31(0) 317480700$

www.wur.eu/environmental-research

Report 3024

ISSN 1566-7197
The mission of Wageningen University \& Research is "To explore the potential of nature to improve the quality of life". Under the banner Wageningen University \& Research, Wageningen University and the specialised research institutes of the Wageningen Research Foundation have joined forces in contributing to inding solutions to important questions in the domain of healthy food and living environment. With its roughly 30 branches, 5,000 employees and 12,000 students, Wageningen University \& Research is one of the leading organisations in its domain. The unique Wageningen approach lies in its integrated approach to issues and the collaboration between different disciplines. 